\title{
Development of Internet literacy self-efficacy scale for pre-service teachers
}

\author{
Nehir Yasan Ak \\ Gaziosmanpasa University, Department of Computer Technologies, Tokat, Turkey, nehir.yasanak@ gop.edu.tr
}

\begin{abstract}
This study aims to develop the Internet Literacy Self-Efficacy Scale (ILSEF) that can be used to examine pre-service teachers' beliefs in their capabilities to perform recent web functionalities. The data was collected from eight different departments and all grade levels of the faculty of education at a state university in Turkey. Two different samples were used to develop and validate the instrument. The first and second samples consisted of 174 and 150 pre-service teachers, respectively. In an effort to explore the factorial structure, exploratory factor analysis was run with sample 1 . A four-factor structure with 16 items was obtained: trustworthiness, creation, technical knowledge, and getting information. This structure accounted for $65.40 \%$ of the total variance. For structural model validation, the proposed model was evaluated with four alternative models. Construct validity was also checked by convergent and discriminant validity. In order to confirm the four-factor solution model of ILSEF, confirmatory factor analysis was performed with sample 2. Cronbach alpha internal consistency coefficients of each factor ranged from .91 to .72 . The results provided some evidence that the scores obtained from the Internet Literacy Self-Efficacy Scale are valid and reliable in assessing pre-service teachers' self-efficacy beliefs in terms of the Internet use knowledge and skills.
\end{abstract}

Keywords: Educational technology, Instrument development, Internet literacy, Pre-service teachers, Selfefficacy

\section{Öğretmen adayları için İnternet okuryazarlı̆̆ özyeterlik ölçeğinin geliştirilmesi}

ÖZ Bu çalışma, öğretmen adaylarının güncel web işlevlerini kullanabilme yetenekleriyle ilgili inançlarını incelemek için kullanılabilecek İnternet Okuryazarlığı Özyeterlik Ölçeğini (ILSEF) geliştirmeyi amaçlamaktadır. Veriler, Türkiye'deki bir devlet üniversitesindeki eğitim fakültesinin sekiz farklı bölümünden ve tüm sınıf düzeylerinden toplanmıştır. Ölçeğin geliştirilmesi ve güvenirlik çalışmaları için iki farklı örneklem kullanılmıştır. Birinci örneklem 174 ve ikinci örneklem 150 öğretmen adayından oluşmaktadır. Faktöriyel yapıyı araştırmak için birinci örneklem ile açımlayıcı faktör analizi yapılmıştır. 16 maddelik dört faktörlü bir model elde edilmiştir: güvenilirlik, oluşturma, teknik bilgi ve bilgi alma. Bu model toplam varyansın \%65,40'ını açıklamıştır. Yapısal model geçerliği için, önerilen model ile birlikte dört alternatif model değerlendirilmiştir. Yapı geçerliği ayrıca yakınsak ve ayırt edici geçerlik ile kontrol edilmiştir. ILSEF'in dört faktörlü çözüm modelini doğrulamak için ikinci örneklem ile doğrulayıcı faktör analizi yapılmıştır. Her bir faktör için Cronbach alfa iç tutarlılık katsayıları .91 ile .72 arasında değişmektedir. Sonuçlar, İnternet Okuryazarlığı Özyeterlik Ölçeğinden elde edilen puanların, ögretmen adaylarının İnternet kullanım bilgi ve becerilerine olan özyeterlik inançlarını değerlendirilmesinde geçerli ve güvenilir bir yapıda olduğunu ortaya koymuştur.

Anahtar $\quad$ Ĕ̆itim teknolojisi, Internet okur-yazarlı̆̆l, Öğretmen ĕgitimi, Ölçek geliştirme, Özyeterlik

Citation: $\quad$ Yasan Ak, N., (2020). Development of Internet literacy self-efficacy scale for pre-service teachers. Turkish Journal of Education, 9(2), 179-204. DOI: 10.19128/turje.664706 


\section{INTRODUCTION}

The International Telecommunication Union (ITU) reported that four billion people had an Internet connection in 2016. According to this report, the number of Internet users is dramatically increasing year-by-year; and only in five years, the number of users has doubled. However, Internet access cannot be considered as simply switching on any device or just making a simple search in 'Google'; some skills and knowledge are needed to engage with online facilities (Livingstone, Bober, \& Helsper, 2005). In the literature, these skills and knowledge requirements are defined by using several terms such as Internet literacy, media literacy, information literacy, digital literacy, and ICT literacy. All these terms serve similar purposes and focus on one common point, which is being able to use and utilize digital technology (e.g. Internet, computer or mobile technologies and information) effectively (Ferrari, 2012). As a broader term, media literacy includes both the Internet and mobile/ computing technologies. Hence, Internet literacy can more specifically be thought of as a component of media literacy. Livingstone et al. (2005) defined media literacy as "the ability to access, understand and create communications in a variety of forms" (p.6). The requirements of Internet literacy are similar to media literacy and have the following three dimensions: (1) Access, (2) Understanding, and (3) Creation.

The more web technologies have new features; the more skills are required. Thus, the importance of Internet literacy, more broadly media literacy, is increasing due to this rapid technological change. For instance, Web 1.0 tools differentiate from Web 2.0 tools in terms of allowing content change, content creation, and active participation (Kıyıc1, 2010). Therefore, the frame for Internet literacy has also been broader by these new functionalities. Undoubtedly, this rapid change in digital technologies influences educational systems. As Angela (2011) indicated, new media technologies enhance the source of information, and this offers new learning environments to teachers and students. Moreover, integration of technology into teaching has become a requirement in the information age (Young, 2015).

\section{Self-Efficacy}

Being one of the affective characteristics situated within the social cognitive theory, self-efficacy is defined by Bandura (1986) as "people's judgments of their capabilities to arrange and execute courses of action required to attain designated types of performance" (p. 391). Simply put, self-efficacy is people's beliefs about their abilities to successfully establish a given task or behavior required to reach a goal. While defining self-efficacy, it is also crucial to consider relevant self-evaluation constructs such as self-concept and self-esteem. At this point, it is essential to define similar self-evaluation constructs such as self-concept and self-esteem to avoid any misconception. Self-concept is defined by Rosenberg (1965) as "...the totality of the individual's thoughts and feelings having reference to himself as an object" (p. 7). Self-efficacy resembles self-concept in predicting people's thoughts, emotions, and actions (Bong \& Skaalvik, 2003). However, the major difference is revealed in the target part. While efficacy judgments concern one's perception of his or her capabilities to accomplish a specific task or situation, self-concept represents one's perception of the self for a domain in general. For example, one's expectation of about 6 feet high-jump is an efficacy judgment (Bandura, 1986). On the other hand, being competent or not in high-jumping is a judgment of self-concept. The difference between self-efficacy and self-esteem is also discussed in the literature. Basically, self-esteem is defined as a person's general feelings of self-worth (Bong \& Clark, 1999) and in fact, it is accepted as an effective component of selfconcept. Both represent one's perception of the self. However, while self-esteem consists of more subjective perceptions rather than factual ones, self-concept includes all of these perceptions (Anderson $\&$ Bourke, 2000). Therefore, self-efficacy can be differentiated from self-concept and self-esteem as it is a more predictive and a rather task-specific construct (Bandura, 1986). 
According to Bandura (1977), there are four major sources of self-efficacy: "performance accomplishment", "vicarious experience", "verbal persuasion", and "physiological states". Performance accomplishment is built on personal mastery experiences, which was emphasized as particularly influential by Bandura (1977). Individuals can enhance their self-efficacy beliefs through successful experiences whereas failures decrease their beliefs. Vicarious experience, as the second source of selfefficacy, is basically modeling other people's achievements. In other words, by observing other people's successful performances despite the difficulties they have, people may persuade themselves that they can also perform as well as them. However, the key requirement for this source is that the person should have a similar background. Otherwise, this observation will not have a significant effect on the selfefficacy belief. Verbal persuasion is the third source for strengthening self-efficacy beliefs. If a person is verbally persuaded by others about his or her capabilities in a realistic boundary, this may help to develop self-efficacy beliefs. However, verbal persuasion is not as effective as performance accomplishments and vicarious experience. The last source is the emotional and physiological state that can influence self-efficacy beliefs. A person who is depressed cannot judge his/her capabilities accurately because depressive mood dampens confidence. The physical situation, like extreme tiredness, also affects personal self-efficacy beliefs. Thus, the fourth way of changing perceived self-efficacy is to decrease people's level of stress, modify their negative emotional moods and alter their physical states in a positive way (Bandura, 1998). Although the influence of successful experiences is usually stronger than other sources, the effects of these sources may depend on the person and the particular situation (Zimmerman, 2000). Since self-efficacy affects the willingness of a person to attempt a task, it has an important effect on their choices, actions, and eventually their lives. People with high self-efficacy are eager to set difficult goals and they try to overcome obstacles they encounter rather than avoiding them. However, since people with low self-efficacy beliefs view the challenges as their personal deficiencies, they do not persist longer when they face negative outcomes. As stated in the study of McCoach, Gable, and Madura (2013), there is a causal relationship between self-efficacy and student academic variables such as academic achievement, academic motivation, occupational interests, and career choices.

\section{Internet Literacy Self-Efficacy}

Recently, the impact of technology use on learning and teaching has been an important research topic (Teo \& Koh, 2010). Being a crucial individual trait, self-efficacy was included in many technologies' acceptance models (Aypay, Çelik, Aypay, \& Sever, 2012; Moran, Hawkes, \& Gayar, 2010; Teo, 2009; Wong, Teo, \& Russo, 2012; Venkatesh \& Davis, 1996; Vankatesh, Morris, Davis, \& Davis, 2003). In most of these studies, self-efficacy was found as a strong predictor. Moreover, different types of selfefficacy such as computer self-efficacy, Internet self-efficacy, and web use self-efficacy in academic settings have been discussed by many researchers. One of them is the study of Tsai and Tsai (2003), which aimed to find the effect of self-efficacy beliefs on information learning strategies and learning. The results showed that students with low Internet self-efficacy had worse information searching strategies than those with high self-efficacy, and also high self-efficacy beliefs affected the students' learning in a positive way. In another study, Liaw, Huang, and Chen (2007) reported that the students' intention of using e-learning was predicted by perceived self-efficacy beliefs. Similarly, Wang, Ertmer, and Newby (2004) found that pre-service teachers' self-efficacy beliefs for technology integration were a strong predictor for examining patterns of classroom computer use. Joo, Bong, and Choi (2000) found that there was a significant relationship between Internet self-efficacy and academic motivation. In another study, Sang, Valcke, van Braak, and Tonderur (2010) reported that pre-service teachers having high computer self-efficacy showed more positive attitudes towards the educational use of computers than those with low self-efficacy. Kaya and Durmuş (2010) examined the relationship between preservice teachers' perceived Internet self-efficacy and levels of Internet use of research. The results showed that Internet self-efficacy significantly differed according to the department, grade level, and frequency of Internet use. The same study also indicated that the seniors had a higher self-efficacy belief than other grade levels, and they also reported a positive relationship between the frequency of Internet use and Internet self-efficacy beliefs. 
As mentioned above, several studies emphasize the importance of self-efficacy beliefs in educational technology use. However, the instrument used in most of these studies (Vankatesh, Morris, Davis, \& Davis, 2003; Moran, Hawkes, \& Gayar, 2010; Laver, George, Ratcliffe, \& Croty, 2012; Joo, Bong, \& Choi, 2010; Terzis, Anastasios, \& Economides, 2011; Sun \& Rueda, 2012) was Computer Self-Efficacy Scale developed by Compeau and Higgins (1995). The scale originally consisted of 11 items with a 10point scale assessing software package use. Other studies modified this scale according to their purposes by selecting some specific items. More specifically, researchers adapted the scale by changing the word "software package" to the tool they used in their studies such as "tablet use", "new technology use", and "Internet use". Furthermore, all items were not used in the aforementioned studies, they rather selected and used four or five items among these 11 items. This indicates that the scale did not propose a comprehensive model due to having the single-factor structure. On the other hand, there are some studies in the literature, especially examining Internet self-efficacy beliefs. Some of them are as follows: Online Technologies Self-Efficacy Scale (OTSES) (Miltiadou \& Yu, 2000), Internet Self-Efficacy (ISE) (Eastin \& LaRose, 2000), Web Users Self-Efficacy Scale (WUSE) (Eachus \& Cassidy, 2006), Use of Internet Self-Efficacy Beliefs Scale for Educational Purposes (Şahin, 2009) and Internet Self-Efficacy Research (ISS) (Kao \& Tsai, 2009). Unlike the Computer Self-Efficacy Scale, they all have a multi-factor structure. Therefore, it can be said that Internet usage has been handled in many dimensions. However, web technologies are changing rapidly, and these scales may not be up to date since they may not include current web functionalities. Besides, these scales were developed for general users or students who were not specifically from the faculty of education. Therefore, this study aimed to develop a reliable and valid Internet self-efficacy scale for pre-service teachers in an educational environment, in which the current web functionalities will be considered.

\section{METHODOLOGY}

\section{Instrument Development}

The instrument was developed to measure Internet literacy self-efficacy beliefs of pre-service teachers. As the first step, the researcher developed an initial item pool of 27 items based on the Internet literacy literature (Lee, Chen, Li, \& Lin, 2015; Kurbanoglu, 2003) and existing technology self-efficacy instruments (Kao, Wu, \& Tsai, 2011; Tella, 2011; Kim, Glassman, Bartholomew, \& Hur, 2013; Şad \& Demir, 2015). The factors of the instrument were determined upon three dimensions of Internet literacy (Livingstone et al., 2005) as follows: (1) access, (2) understanding, and (3) creation. According to this approach, an essential requirement for being Internet literate is to be able to solve Internet access problems and get information effectively. In other words, when faced with some problems related to connection, they have to be able to figure out what these problems are and solve them. Moreover, they can reach the online content they desire. Internet literacy does not only require accessing information but also to be able to evaluate the information in terms of effectiveness and trustworthiness. Lastly, Internet literacy enables users to be producers and to create their content for several purposes. While developing the items and the factors of the instrument, five dimensions were proposed upon the aforementioned dimensions of Internet literacy: (1) Creation, (2) Get Information, (3) Trustworthiness, and (4) Technical Access, (5) Communication.

When deciding on a scale for self-efficacy beliefs, one should be careful about the degree of rating. As Bandura $(1997,2001)$ pointed out, one must avoid providing fewer options since it would be more difficult to differentiate the choices and cause lower reliability and sensitivity. Therefore, a 7-point rating scale ranging from Not at all confident (1) to Extremely Confident (7) was chosen for the developed instrument. For content validity, four experts from Computer Education and Instructional Technology and one expert from Curriculum and Instruction whose expertise was about measurement and evaluation in education revised the items. After revisions of the scale, communication factor with five items was 
deleted because the experts pointed out that the items were low in complexity for the level of undergraduate students. For example, "sending an e-mail to my classmates and teachers." or "communicate via social media with classmates and teachers". Moreover, two items related to Learning Management Systems were removed because the selected university for data collection did not have a system with mentioned functionalities in the items (e.g., "I can upload documents on Learning Management Systems").

Cognitive interviews were done with three students (one of them was from computer education and instructional technology, two of them were from science education), which are important for detecting possible response errors and to find the reasons for these errors in the survey (Willis, 2004). According to these interviews, some items were revised to be more understandable, and also some were shortened to facilitate data collection. For instance; "While I am searching on the Internet, I feel confident about reaching the information that I am looking for." changed as "I can use Google search techniques effectively". Another item, "While I am looking for resources, I feel confident about how to use library databases." was revised as "I can use online library databases effectively". Moreover, two items from trustworthiness factor were deleted because of not being clear (e.g., I trust my strategies for evaluating the trustworthiness of the information shared on social media."). During these interviews, it was realized that example tools given in brackets may cause misunderstanding. The students responded to the item according to whether they used the exact example tool or not. To prevent this, "For instance" was added at the beginning of the examples to emphasize that the given tools are only examples and were not the only options and indeed alternative ones were also possible. Furthermore, some words needed explanations, such as "podcast". For some items, "...on the web" was added to highlight the activity was performed on the web. For example, "I can create presentation" can be understood as "create presentation on Microsoft PowerPoint". After all revisions, the scale resulted in 19 items with four dimensions as seen in Table 1.

Table 1.

The dimensions and sample items in the Internet literacy self-efficacy scale

\begin{tabular}{lcll}
\multicolumn{1}{c}{ Dimensions } & $\begin{array}{c}\text { Number of } \\
\text { items }\end{array}$ & \multicolumn{1}{c}{ Items } & \multicolumn{1}{c}{ Sample Item } \\
\hline Creation & 6 & $\mathrm{i} 4, \mathrm{i} 7, \mathrm{i} 12, \mathrm{i} 14, \mathrm{i} 15, \mathrm{i} 19$ & I can create presentations on the web. \\
Get Information & 6 & $\mathrm{i} 1, \mathrm{i} 2, \mathrm{i} 9, \mathrm{i} 10, \mathrm{i} 11, \mathrm{i} 18$ & I can use online library databases. \\
Trustworthiness & 4 & $\mathrm{i} 3, \mathrm{i} 5, \mathrm{i} 13, \mathrm{i} 16$ & I can distinguish trustworthy websites. \\
Technical & 3 & $\mathrm{i} 6, \mathrm{i} 8, \mathrm{i} 17$ & $\begin{array}{l}\text { I can solve hardware-related Internet } \\
\text { connection problems. }\end{array}$ \\
Knowledge & & &
\end{tabular}

During instrument development procedure, the researcher's experience about the educational use of technology in the doctoral study (Yasan-Ak, 2018) was also taken as a reference while developing the items and the factors of the instrument.

\section{Participants}

\section{Sample 1}

Sample 1 consisted of 174 pre-service teachers who were selected by nonrandom convenience sampling from a Turkish state university. Of 174 students, 98 were female (\%56.3), $73(\% 42.0)$ were male. While two students did not give a response to the gender item, one student indicated as "other". The students were from 8 different departments of the faculty of education. The distribution was as follows: the majority of the students $(n=64)$ was from Social Science Education $(\% 36,8) ; 26$ of them were from Early Childhood Education (\%14.9); 22 of them were from Guidance and Psychological Counseling Program (\%12.6); 22 of them were from Turkish Language Education (\% 12.6); 14 of them were from Science Education (\%8.0); 10 of them Primary Education (\%5.7); eight of them were from English Language Education (\%4.6); and eight of them were from Elementary Mathematics Education (\%4.6). All grade levels were included in the study: 28 of the sample were freshman students (\%16.1), 27 of 
them were sophomores (\%15.5), 66 of them were juniors (\%37.9), and 51 of them were seniors (\%29.3). Two of them did not indicate their department information as seen in Table 2.

Table 2.

Distribution of the gender, departments, and study year

\begin{tabular}{llrr}
\hline \multicolumn{1}{c}{ Variables } & \multicolumn{1}{c}{$f$} \\
\hline \multirow{5}{*}{ Gender } & Female & 98 & 56.3 \\
& Male & 73 & 42.0 \\
& Other & 1 & .6 \\
& Missing & 2 & 1.1 \\
& Social Science Education & 64 & 36.8 \\
& Science Education & 14 & 8.0 \\
& Psychological Counseling and Guidance & 22 & 12.6 \\
Departments & Early Childhood Education & 26 & 14.9 \\
& Turkish Language Education & 22 & 12.6 \\
& Elementary Mathematics Education & 8 & 4.6 \\
& English Language Education & 8 & 4.6 \\
& Primary Education & 10 & 5.7 \\
& Freshman (1.) & 28 & 16.1 \\
Study Year & Sophomore (2.) & 27 & 15.5 \\
& Junior (3.) & 66 & 37.9 \\
& Senior (4.) & 51 & 29.3 \\
TOTAL & Missing & 2 & 1.1 \\
& & 174 & 100.0 \\
\hline
\end{tabular}

Descriptive statistics of age, GPA, ICT course taken or not taken, course number, Internet use, ICT use level of instructors in courses, and ICT use level of students were revealed in Table 3 . The mean age of participants was $20.97(S D=1.99)$ ranged between 18 and 31. The mean score of the participants' GPA was $3.14(S D=.37)$. While the number of participants who have taken the ICT course was 149 , and the remaining 23 participants have not taken any ICT courses. The number of courses the participants have taken ranged between 1 and $6(M=1.87, S D=0.95)$. Internet use of the participants ranged from 0 to 15 hours $(M=4.83, S D=2.82)$. Depend on the participants' evaluation, ICT use level of instructors in courses had a mean score of 6.46 out of $10(S D=2.30)$; and ICT use level of students while doing homework had a mean score of 8.30 out of $10(S D=2.04)$.

Table 3.

Descriptive statistics

\begin{tabular}{|c|c|c|c|c|c|}
\hline \multirow{2}{*}{$\begin{array}{l}\text { Variable } \\
\text { Age }\end{array}$} & & M & SD & $\mathrm{f}$ & $\%$ \\
\hline & & 20.97 & 1.99 & - & - \\
\hline & - & - & 2 & 1.1 & \\
\hline \multirow[t]{3}{*}{ GPA } & & 3.14 & .37 & - & - \\
\hline & - & - & 28 & 16.1 & \\
\hline & - & - & 19 & 10.9 & \\
\hline \multicolumn{6}{|l|}{ ICT Course } \\
\hline & Taken & - & - & - & - \\
\hline & Not taken & - & - & 149 & 85.6 \\
\hline & Missing & - & - & 23 & 13.4 \\
\hline \multirow[t]{2}{*}{ Course Number } & & 1.87 & .95 & - & - \\
\hline \multirow{2}{*}{\multicolumn{2}{|c|}{ Internet use (in hours) }} & - & - & 2 & 1.1 \\
\hline & & 4.83 & 2.82 & - & - \\
\hline & Missing & & & 3 & 1.7 \\
\hline \multicolumn{2}{|c|}{ ICT use level of instructors in courses } & 6.46 & 2.30 & - & - \\
\hline & Missing & - & - & 2 & 1.1 \\
\hline \multirow{2}{*}{\multicolumn{2}{|c|}{$\begin{array}{c}\text { ICT use of level students in homework } \\
\text { Missing }\end{array}$}} & 8.30 & 2.04 & - & - \\
\hline & & - & - & 2 & 1.1 \\
\hline
\end{tabular}




\section{Sample 2}

The second sample comprised of 150 pre-service teachers from different departments of education faculty at a public university in Turkey. All departments indicated in sample 1 were included in sample 2 as well. 8 of them were removed because students did not fill out the questionnaire properly. Out of 142 students, 94 were female $(66.2 \%)$ and 48 were male students $(33.8 \%)$. The age range was between 18 and 30 years old $(M=20.89, S D=1.74)$.

\section{Data Collection Procedure}

Ethical approval was obtained for the relevant university from the Applied Ethics Research Center before data collection. The data were collected in the fall semester of 2017-2018 and the spring semester of 2018-2019. Since the scale measures technological ability, the researcher chose a hand-delivered questionnaire. The online survey may result in low internal validity. The survey took about 10 minutes to complete. Students participated in the study voluntarily and also informed about the confidentiality of their answers.

\section{Data Analysis}

The instrument had two main parts. While the first part was the developed scale, the second part of the instrument was the demographic information including gender, age, year of study, department, and GPA. The second part also included some technology use related questions as follows: the number of courses taken in the undergraduate programs, daily Internet use, ICT use level of instructors in courses, and ICT use level of students in homework. The descriptive analysis was presented with the frequencies, percentages, means, and standard deviations.

To develop a valid and reliable Internet literacy self-efficacy scale, two independent samples were used in the current study. Firstly, in order to explore the underlying constructs of the instrument, exploratory factor analysis (EFA) was conducted. Principal Axis Factoring extraction method with Oblimin rotation was used. Secondly, confirmatory factor analysis (CFA) was run to validate the factorial structure of the developed scale. Then, construct validity was also checked by two methods: (a) convergent validity, and (b) discriminant validity. Finally, sample 1 and sample 2 were used for the reliability analyses. Both results were reported, separately.

SPSS 20.0 was used to conduct descriptive and exploratory factor analyses whereas confirmatory factor analysis was performed by using AMOS 20.0 software.

\section{RESULTS}

\section{Pilot Study}

\section{Exploratory factor analysis (a)}

Before conducting exploratory factor analysis, missing data were examined in the data. Because of being less than $5 \%$ on a single variable, it was ignored based on the suggestion of Hair, Anderson, Tatham, and Black (2010). There are several methods to handle missing values such as deleting cases, single imputation, and multiple imputations (Kline, 2011). The researcher used multiple imputation methods, which is "the most respectable method to deal with missing data" (Tabachnick \& Fidell, 2013, p. 72). 
The sample size for conducting EFA was checked in two ways. Firstly, according to Hatcher (1994), 5:1 rule, means five cases for each item, or being above 100 cases was acceptable to run EFA. The rules were met for 19 items with 174 cases. Secondly, Kaiser-Meyer-Olkin (KMO) is an alternative way to check the adequacy of sample size (Field, 2009). Since KMO value (.84) was between .8 and .9 , it was accepted as a great value for sampling adequacy according to Hutcheson and Sofroniou (1999, as cited in Field, 2009). As another assumption, univariate normality was checked by Skewness and Kurtosis values, Kolmogorov Smirnov and Shapiro Wilk tests, histograms, and Q-Q plots. Firstly, z scores of Skewness and Kurtosis were calculated and it was found that absolute values of $\mathrm{z}$ score less than 1.96. They were not significantly different from the null hypothesis at $p>.05$ (Field, 2009). Thus, the variables showed a normal distribution. Moreover, histograms and Q-Q plots were examined. It was not observed any serious concern to prevent normality. Lastly, Kolmogorov Smirnov and Shapiro Wilk tests were found significant at $p=.00$, which is an indicator of non-normal distribution (Field, 2009). However, it was concluded that the normality assumption was met based on Skewness and Kurtosis values, histogram and Q-Q plots. Multivariate normality was also checked through Mardia's test. It was found significant $(p=.00)$, which means the multivariate normality was violated. Thus, Principal Axis Factoring (PAF) extraction method was used based on the suggestions of Fabrigar, Wegener, MacCallum, and Strahan (1999). On the other hand, the data were screened to detect outliers. Firstly, each item was converted to standardized z-scores. Any value exceeding absolute 3.29 would determine as an outlier (Tabachnick \& Fidell, 2013), which was not observed in the data set. Moreover, box plots were examined. There were only a few dots fall away from the box. Thus, it can be said that there was not any univariate outlier. Yet, multivariate outliers were also checked to guarantee the absence of outliers. The Mahalanobis distance $\left(D^{2}\right)$ and chi-square were calculated for each case. Nine (63., 73., 90., 105., 156., 112., 116., 135., and 153. cases) out 174 participants were detected as multivariate outliers with the critical value of $43.820(d f=19, p=.001)$. They were removed from the data before conducting EFA. Lastly, the appropriateness of EFA was checked through correlation matrix and Barlett's test of sphericity. According to Tabachnick and Fidell (2009), if correlation coefficients are not above .30, there is no need to conduct EFA. After examining the correlation matrix, it was seen that many correlations which exceed this threshold. Moreover, Barlett's test of sphericity was found significant $\left(\chi^{2}(171)=1402.16, p=.00\right)$ at the .05 level, which indicates the presence of nonzero correlations. As indicated above, since multivariate normality assumption was not met, Principal Axis Factoring was chosen as an extraction method. Moreover, oblique rotation, more specifically direct oblimin was chosen as factor rotation because of the presence of correlated factors. (Preacher \& McCallum, 2003).

In order to determine the number of factors, the screen test, Kaiser's eigenvalues, and Horn's parallel analysis were checked. When EFA was firstly run, the pattern matrix with 5 factors was observed. The rule of thumb for factor loadings is determined above .30 (Hair et al., 2010). As being one of the items of Getting Information factor, Item 2 was cross-loaded both on Trustworthiness (first) and Creation (second) factors in the first run. Thus, it was removed. After removing Item 2, EFA was run secondly. Item 1 was removed due to not loading any factor. After removing those 2 items, the EFA was conducted again with 17 items. Since Item 11 had low loading, it was removed as well. Finally, EFA was performed with 16 items. Item 9 was cross-loaded both on Trustworthiness and Getting Information factors. It was one of the items of Getting Information factor and loaded higher on that factor than Trustworthiness. Thus, Item 9 remained under Getting Information factor. As seen in Figure 1, an approximately horizontal line started at the fourth factor in the scree pilot, which indicated the presence of four factors. 


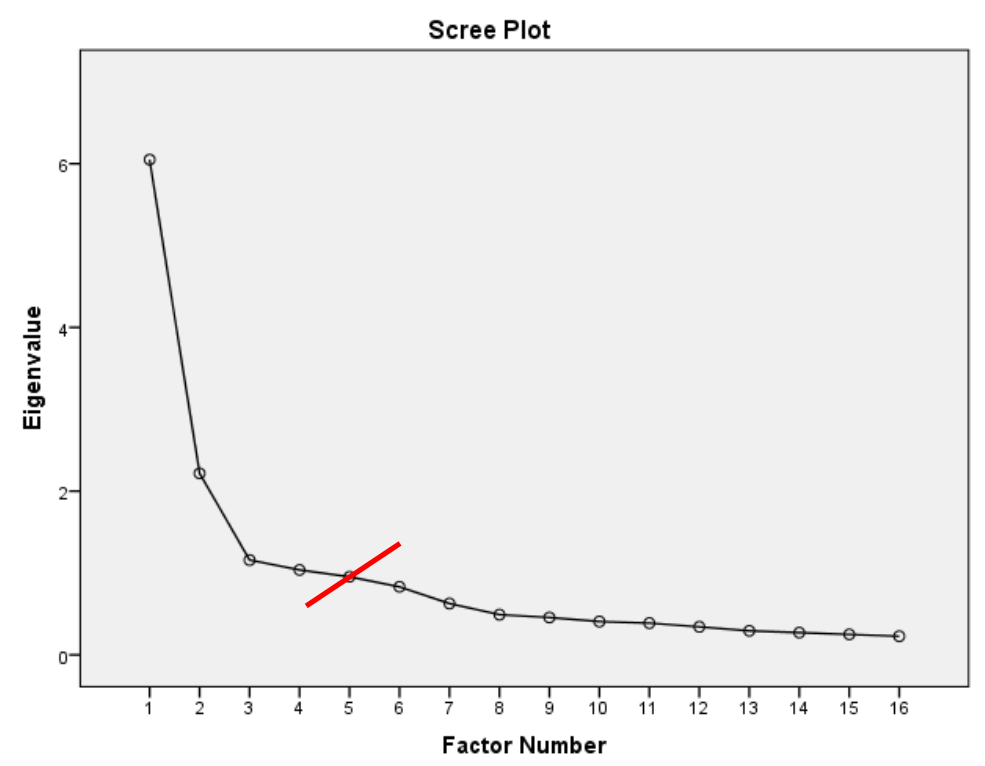

Figure 1. Scree plot of eigenvalues of factors in Internet literacy self-efficacy scale.

However, the scree plot is not enough for the interpretation of the numbers of factors since it depends on the researchers' judgments (Tabachnick \& Fidell, 2009). Thus, Kaiser's eigenvalues were also examined to decide a reliable estimation of the number of factors. According to Tabachnick and Fidell (2009), eigenvalues less than 1 are not important for a variance. As seen in Table 4, there were four factors explaining $65.40 \%$ of the total variance in the study. Factor 1, 2, 3, and 4 accounted for 37.82, $13.86,7.24$, and 6.48 of the total variances, respectively. Furthermore, it was found that correlation among four factors from $|.39|$ to $|.59|$, which indicates that the choice of using an oblique rotation method was proper.

Table 4.

Results of eigenvalues and extraction sums of squared loadings

\begin{tabular}{lrrrrr}
\hline \multirow{2}{*}{ Factor } & \multirow{2}{*}{ Total } & \multicolumn{3}{c}{ Initial Eigenvalues } & \multicolumn{3}{c}{ Extraction Sums of Squared Loadings } \\
\cline { 3 - 6 } & & \% of Variance & Cumulative \% & \% of Variance & Cumulative\% \\
\hline 1 & 6.05 & 37.82 & 37.82 & 5.62 & 35.09 \\
2 & 2.22 & 13.86 & 51.68 & 1.79 & 11.17 \\
3 & 1.16 & 7.24 & 58.92 & .78 & 4.84 \\
4 & 1.04 & 6.48 & 65.40 & .59 & 3.72 \\
5 & .95 & 5.96 & 71.36 & & \\
6 & .83 & 5.19 & 76.55 & & \\
7 & .63 & 3.92 & 80.47 & & \\
8 & .49 & 3.07 & 83.54 & & \\
9 & .46 & 2.85 & 86.39 & & \\
10 & .41 & 2.54 & 88.93 & & \\
11 & .39 & 2.42 & 91.36 & & \\
12 & .34 & 2.14 & 93.49 & & \\
13 & .29 & 1.83 & 95.33 & & \\
14 & .27 & 1.70 & 97.02 & & \\
15 & .25 & 1.56 & 98.58 & & \\
16 & .23 & 1.42 & 100.00 & & \\
\hline
\end{tabular}

As seen in Table 5, four factors were obtained. Items 3, 5, 13 and 16 were loaded on Factor 1 labeled as trustworthiness; items 4, 7, 12, 14, 15 and 19 were loaded on Factor 2 labeled as creation; items 6, 8, and 17 were loaded on Factor 3 labeled as technical knowledge, and items 9, 10 and 18 were loaded on Factor 4 labeled as getting information. 
Table 5.

Items and factor loadings from four-factor solution with oblimin-rotation: Eigenvalues and percentage of variance

\begin{tabular}{|c|c|c|c|c|c|}
\hline & & \multicolumn{4}{|c|}{ Factor } \\
\hline & & 1 & 2 & 3 & 4 \\
\hline \multirow{4}{*}{ Trustworthiness } & $\begin{array}{l}\text { 3. I can distinguish whether information on the web is } \\
\text { subjective or scientific. }\end{array}$ & .86 & -.05 & .02 & .03 \\
\hline & $\begin{array}{l}\text { 5. I can distinguish whether the source of information } \\
\text { on the web is scientific or not. }\end{array}$ & .75 & -.05 & -.06 & -.05 \\
\hline & 13. I can distinguish trustworthy web sites. & .68 & .07 & -.06 & .04 \\
\hline & $\begin{array}{l}\text { 16. I can distinguish whether information on the web is } \\
\text { trustworthy. }\end{array}$ & .61 & .06 & -.11 & -.15 \\
\hline \multirow{6}{*}{ Creation } & 4. I can create videos on the web. & .08 & .76 & .04 & .19 \\
\hline & 14. I can create posters or concept maps. & .05 & .76 & .01 & .05 \\
\hline & 19. I can create surveys. & -.14 & .69 & -.12 & -.18 \\
\hline & 12. I can create blogs. & -.05 & .58 & .00 & -.20 \\
\hline & 15. I can create presentations on the web. & .01 & .51 & .03 & -.32 \\
\hline & 7. I can create podcasts. & .05 & .50 & -.23 & -.02 \\
\hline \multirow{3}{*}{$\begin{array}{l}\text { Technical } \\
\text { Knowledge }\end{array}$} & 8. I can solve software-related Internet access problems. & -.07 & -.05 & -.87 & -.04 \\
\hline & 6. I can solve other Internet access problems. & .12 & .03 & -.76 & .04 \\
\hline & $\begin{array}{l}\text { 17. I can solve hardware-related Internet access } \\
\text { problems. }\end{array}$ & .07 & .04 & -.72 & .03 \\
\hline \multirow{5}{*}{$\begin{array}{l}\text { Getting } \\
\text { Information }\end{array}$} & 10. I can use online library databases. & .10 & -.01 & -.09 & -.75 \\
\hline & 18. I can use academic reference programs. & .11 & .14 & -.14 & -.34 \\
\hline & 9. I can use Google search techniques. & .31 & .10 & .02 & -.32 \\
\hline & Eigenvalues & 6.05 & 2.22 & 1.16 & 1.04 \\
\hline & $\%$ of Variance & 37.82 & 13.86 & 7.24 & 6.48 \\
\hline
\end{tabular}

Extraction Method: Principal Axis Factoring. Rotation Method: Oblimin with Kaiser Normalization.

Note. Factor loadings over .30 appear in bold.

Kaiser's eigenvalue-greater-than-one rule is accepted as the most popular method in practice. Moreover, it was also seen as a method which gives the number of factors that would most accurately reveal the relationships between the items (Büyüköztürk, 2007). However, this rule has been found to be problematic and inefficient in determining the number of factors by some researchers (Ladesma \& Pedro, 2007). Thus, the parallel analysis (PA), which was accepted as the best alternative and appropriate method in various studies (Humphreys \& Montanelli, 1975; Zwick \& Velicer, 1986), was also performed. As seen in Table 6, the second column shows the Kaiser's eigenvalues and the last column shows the PA eigenvalues. Accordingly, Kaiser's eigenvalues of the first two factors were larger than the eigenvalues of PA, but not the third and the fourth factors. Thus, it was concluded that the number of factors was two based on the parallel analysis, and the other two factors were obtained by chance.

Table 6.

Results of parallel analysis

\begin{tabular}{cccc}
\hline Factor & Kaiser's Eigenvalues & Mean of Eigenvalues & PA eigenvalues \\
\hline $1^{*}$ & 6.05 & 1.58 & 1.68 \\
$2^{*}$ & 2.22 & 1.45 & 1.53 \\
3 & 1.16 & 1.35 & 1.42 \\
4 & 1.04 & 1.27 & 1.32 \\
\hline
\end{tabular}

Three methods used to determine the number of factors on the scale. While the screen test and Kaiser's eigenvalues proposed a four-factor structure model, a two-factor structure was obtained in the parallel analysis. In order to decide the number of factors, structural model validation was done. More specifically, five alternative models including two-factor measurement model and four-factor measurement model were tested. Then, to evaluate item - latent construct relationship, construct validity was examined by convergent and discriminant validity. Accordingly, the results showed that the number of factors to be retained was four. The detail was given below. 


\section{Structural model validation (b)}

A measurement model refers to the linear or nonlinear statistical functions involving the relation between items and constructs to be measured (Yurdugül \& Aşkar, 2008). In order to evaluate the proposed measurement model and alternative models, first-order confirmatory factor analyses were performed. The data consisted of 165 undergraduate students. In order to investigate factorial validity, five measurement models were used, which were given in the explanations below.

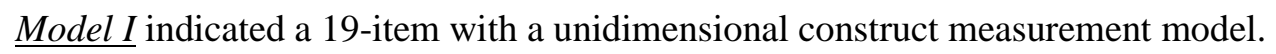

Model II indicated a two-factor measurement model as proposed in the parallel analysis. An exploratory factor analysis was run for obtaining a two-factor structure model. Principal Axis Factoring was selected as the extraction method. Only Item 2 was deleted because of being under .30 (Hair et al., 2010). While the first factor included 10 items, the second factor consisted of eight items.

Model III indicated a four-factor measurement model which was obtained in the present study. Principal Axis Factoring was selected as the extraction method. The model included 16 items, and the factors were as follows: Trustworthiness, Creation, Technical Knowledge, and Getting Information. In this model, the four latent factors were considered to be correlated.

Model IV indicated a four-factor measurement model which was obtained in the present study, where the latent factors were considered to be uncorrelated.

Model V (Empirical Measurement Model) indicated a four-factor measurement model which was obtained in the present study, and the factors were correlated. Differently, in order to improve modelfit, some error variances were allowed covarying in this model.

The following fit indices were chosen to compare alternative models: root mean square error of approximation (RMSEA), chi-square ( $\chi 2) / \mathrm{df}$, comparative fit index (CFI), and non-normed fit index (NNFI). The model-data fits were computed for all of the measurement models, which were presented in Table 7. The table also shows the criteria for good-fit-indices with their references.

Table 7.

Good-of-fit indices and comparison of the measurement models

\begin{tabular}{llllll} 
& & RMSEA $^{\mathrm{a}}$ & $\chi 2 / d f^{\mathrm{b}}$ & $\mathrm{CFI}^{\mathrm{c}}$ & $\mathrm{NNFI}^{\mathrm{c}}$ \\
\cline { 3 - 6 } & & $<.10$ & $<.3 .0$ & $\geq .90$ & $\geq .90$ \\
\hline Model I: & Unidimensional Model & .14 & 4.13 & .63 & .59 \\
Model II: & Two-factor Structure & .11 & 3.12 & .75 & .78 \\
Model III: & Four-factor Structure (Correlated) & .08 & 2.17 & .90 & .88 \\
Model IV: & Four-factor Structure (Uncorrelated) & .13 & - & .76 & .73 \\
Model V: & Four-factor Structure (correlated- covaried) & .08 & 1.86 & .92 & .90 \\
\hline
\end{tabular}

References: ${ }^{\mathrm{B} B r o w n}$ and Cudeck (1993), ${ }^{\mathrm{b}} \mathrm{Hu}$ and Bentler (1999), ${ }^{\mathrm{c}} \mathrm{Kline}(2011)$

Firstly, Model I was built, which was a unidimensional model with 19-item. According to the fit indices of the model, Model I showed a poor model fit. This can be interpreted as an indicator that the scale consisting of 19 items did not confirm the one-factor structure model, but it should have more than one sub-construct. Secondly, Model II was based on the two-factor structure model as the parallel analysis proposed, which included 18-items. Although an improvement was observed in the fit indices compared to Model I, it was not sufficient for a good model fit. This was also proof that the scale was not suitable for the two-factor structure model with 18-item. Thirdly, the present study proposed Model III, in which a four-factor structure (correlated) model was obtained from the pilot study. In this model, the number of items dropped from 19 to 16 items. Again, the fit indices showed an improvement, but an insufficient level. Similar to Model III, Model IV indicated a three-factor structure model obtained from the present study, but the latent factors were assumed to be uncorrelated. As seen in Table 7, a decline was observed 
in the good-of-fit indices of the model. Finally, Model V was built, which was a four-factor measurement model with 16 items. The latent factors were correlated; and six error covariances ( $\varepsilon 8-\varepsilon 9, \varepsilon 9-\varepsilon 16, \varepsilon 10-$ $\varepsilon 14, \varepsilon 12-\varepsilon 14, \varepsilon 13-\varepsilon 14$, and $\varepsilon 14-\varepsilon 15)$ were found highly relatively in the program output. Two experts from Computer Education and Instructional Technology examined the relevant items to decide covary. Firstly, four error covariances under creation factor were assessed. It was seen that item 7 "I can create podcasts." was related to other four items "creating blogs", "creating posters or concept maps", "creating surveys", and "creating presentations on the web". The experts allowed covarying in the model because all the tasks specified in the items are the functionalities of Web 2.0 technologies that enable students to create their own content and share it with other users (Greenhow, Robelia, \& Hughes, 2009). Then, the other two covariances were under getting information factor was evaluated. Item 9 "I can use Google search techniques." was related to item 10 "I can use online library databases." and item 18 "I can use academic reference programs.". The experts pointed out that all these items are related to students' search skills which required technical knowledge. These skills are also considered as an essential $21^{\text {st }}$ century skill because of enhancing productivity and quality of online life (Hill, Jensen, Read, \& MacArthur, 2013). Thus, they allowed covarying in the model as well. According to the fit indices, Model V was found as the most appropriate among five measurement models. Consequently, it was continued with Model V based on these results in the current study. Figure 2 presented the factor loadings of a three- factor solution model (Model V). The abbreviations in the figure as follows: Trust: Trustworthiness, Creat: creation, TechKnow: Technical Knowledge, and Inform: Getting Information.

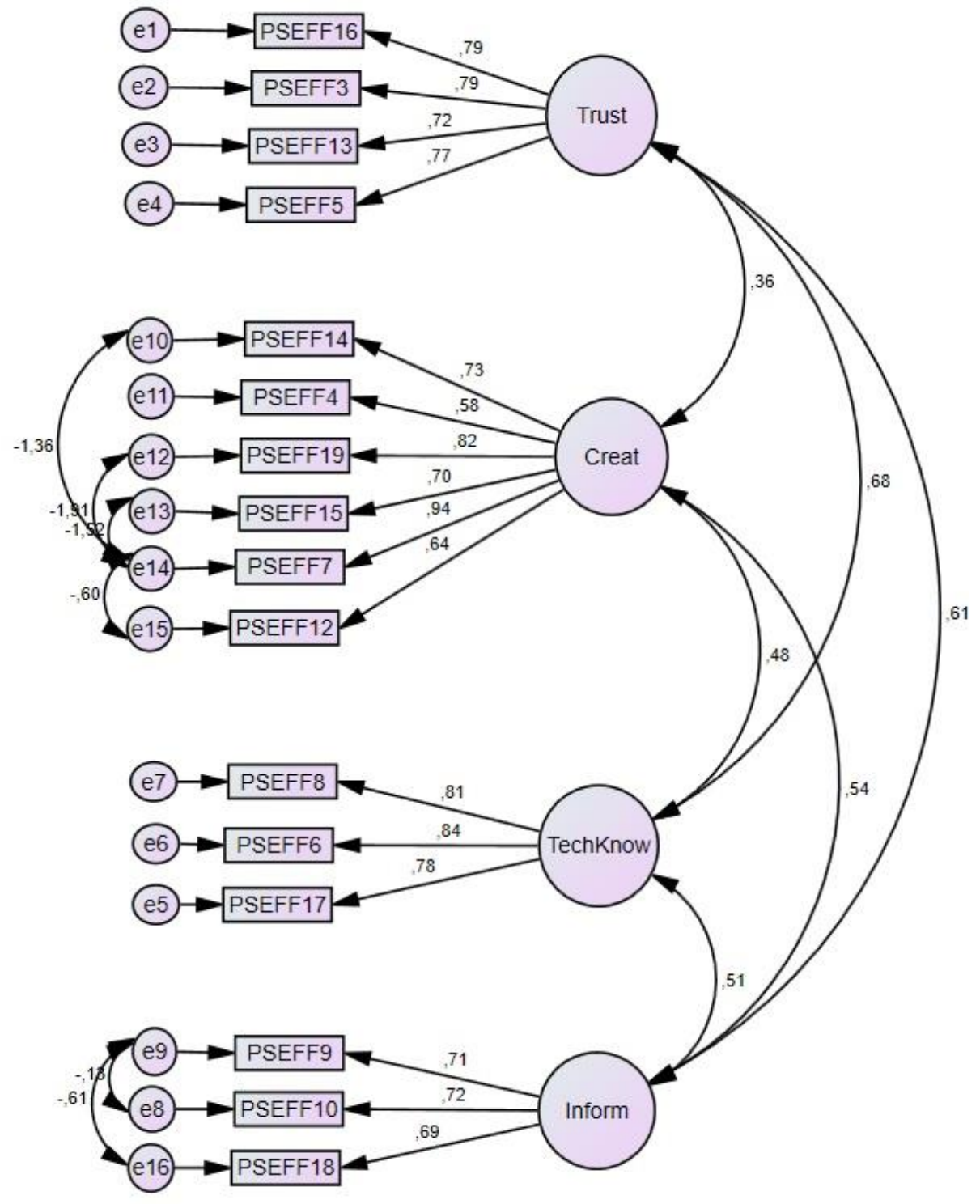

Figure 2. The measurement model (Model V) 


\section{Construct validity (c)}

To evaluate construct validity, convergent validity and discriminant validity were also checked. Construct validity is defined as "the extent to which a set of measured items actually reflects the theoretical latent construct those items are designed to measure" (Hair et al., 2010, p. 618). Therefore, it is related to "accuracy of measurement". In the present study, construct validity was examined in two ways: (1) convergent validity, and (2) discriminant validity (Yurdugül \& Sirakaya, 2013).

(1) Convergent validity of the measurement model was measured by using three ways. Firstly, the size of factor loadings was checked. As seen in Figure 1, the factor loadings were between .58 and .94, which met the rule that standardized factor loadings should be greater than .50 (Hair et al., 2010).

Secondly, the average variance extracted (AVE) was calculated by the calculator provided by Gouveia and Soares (2015), which were between .50 and .66. The rule of thumb for AVE is that .50 or higher suggest good validity (Hair et al., 2010). Thus, it can be concluded that the AVE values for each factor were acceptable. Lastly, composite (construct) reliability (CR) was calculated as an indicator of convergent validity. As seen in Table $8, \mathrm{CR}$ values were obtained between .75 and .88 , which were acceptable according to the rule of thumb greater 70 (Hair et al., 2010).

Table 8.

Convergent validity for the measurement model

\begin{tabular}{lccc}
\hline & $L$ Interval (a) & AVE (b) & CR (c) \\
\hline Trustworthiness & $.72-.79$ & .60 & .85 \\
Creation & $.58-.94$ & .55 & .88 \\
Technical Knowledge & $.78-.84$ & .66 & .85 \\
Getting Information & $.69-.72$ & .50 & .75 \\
\hline
\end{tabular}

L: Factor Loadings, AVE: Average Variance Extracted, CR: Composite Reliability

(2) Discriminant Validity measures "how a construct is actually distinct from the other constructs" (Hair et al., 2010, p. 618). For this, the correlations among the subscales of the ILSEF and the square root of AVE were used. Accordingly, the square root of AVE calculated for each dimension must be greater than correlations coefficients between the corresponding sub-dimension and remaining sub-dimensions. These calculated values must be higher than .50 as well (Fornel \& Larcker, 1981). For example, as seen in Table 9, the square root of AVE was calculated as .77 for trustworthiness dimension, which is higher than correlation coefficients between this sub-dimension and other sub-dimensions.

Table 9.

Discriminant validity for the measurement model

\begin{tabular}{lllll}
\hline & $(1)$ & $(2)$ & $(3)$ & $(4)$ \\
\hline Trustworthiness (1) & $(.77)$ & & - & - \\
Creation (2) & .36 & $\mathbf{( . 7 4 )}$ & - & - \\
Technical Knowledge (3) & .68 & .48 & $\mathbf{( . 8 1 )}$ & - \\
Getting Information (4) & .61 & .54 & .51 & $\mathbf{( . 7 1 )}$ \\
\hline
\end{tabular}

*The values in parentheses are the square roots of AVE

\section{Reliability (d)}

According to the results of factor analysis, Internet Literacy Self-Efficacy (ILSEF), proposed four constructs, namely, trustworthiness, creation, technical knowledge and getting information. For the reliability of the instrument, internal consistency reliability coefficients for each factor were computed. The Cronbach alpha coefficients of the factors are $.89, .81, .83$, and .65, respectively (See Table 10). The rule for acceptable reliability coefficients is determined above .70 (Field, 2009; Kline, 1999). However, as Nunnally (1967) stated that the reliability of .60 was sufficient even though this value was changed as .70 in the other study of Nunnally (1978). Some other scholars also pointed out that the coefficients ranging between .60 and .80 are "somewhat reliable" (Kalayc1, 2008; Akgul \& Çevik, 2003; 
Özdamar, 1997). Moreover, Peterson (1994) and Cortina (1993) stated that Cronbach alpha coefficients depend on the number of items. In other words, fewer items cause low reliability. Thus, it can be concluded that subscales had acceptable internal.

Table 10.

Item-total statistics offactors $(N=165)$

\begin{tabular}{|c|c|c|c|c|c|c|}
\hline & & $\begin{array}{l}\text { Scale Mean if } \\
\text { Item Deleted }\end{array}$ & $\begin{array}{l}\text { Scale Variance if } \\
\text { Item Deleted }\end{array}$ & $\begin{array}{c}\text { Corrected Item-Total } \\
\text { Correlation }\end{array}$ & $\begin{array}{l}\text { Cronbach's Alpha if } \\
\text { Item Deleted }\end{array}$ & $\begin{array}{c}\text { Cronbach's Alpha } \\
\text { of Factors }\end{array}$ \\
\hline \multirow{4}{*}{ Trustworthiness } & i3 & 15.35 & 16.28 & .72 & .80 & \multirow{4}{*}{.85} \\
\hline & i5 & 15.47 & 16.37 & .70 & .81 & \\
\hline & i13 & 15.53 & 16.18 & .65 & .82 & \\
\hline & $\mathrm{i} 16$ & 15.69 & 15.97 & .69 & .81 & \\
\hline \multirow[t]{6}{*}{ Creation } & i4 & 21.88 & 54.33 & .60 & .82 & \multirow{6}{*}{.84} \\
\hline & i14 & 21.64 & 53.39 & .65 & .81 & \\
\hline & i19 & 21.79 & 53.96 & .69 & .80 & \\
\hline & $\mathrm{i} 12$ & 22.10 & 54.02 & .62 & .81 & \\
\hline & i15 & 21.23 & 54.93 & .59 & .82 & \\
\hline & i7 & 22.12 & 57.38 & .56 & .83 & \\
\hline \multirow{3}{*}{$\begin{array}{l}\text { Technical } \\
\text { Knowledge }\end{array}$} & i8 & 9.03 & 10.30 & .74 & .77 & \multirow{3}{*}{.85} \\
\hline & i6 & 8.70 & 10.69 & .72 & .79 & \\
\hline & i17 & 8.85 & 10.56 & .70 & .81 & \\
\hline \multirow{3}{*}{$\begin{array}{l}\text { Getting } \\
\text { Information }\end{array}$} & i10 & 8.75 & 6.31 & .61 & .29 & \multirow{3}{*}{.64} \\
\hline & i18 & 9.50 & 7.31 & .39 & .61 & \\
\hline & i9 & 7.95 & 8.04 & .35 & .66 & \\
\hline
\end{tabular}

\section{Validation Study}

\section{Confirmatory factor analysis (a)}

In order to validate the four-factor solution model of Internet Literacy Self-Efficacy Scale, confirmatory factor analysis was run through AMOS 20.0 (Arbuckle \& Wothke, 1999). For this analysis, Sample 2 was used. Before performing confirmatory factor analysis, the following assumptions were checked, separately: the absence of outliers, normality, and sample size (Tabachnick \& Fidell, 2013). Firstly, both univariate and multivariate outliers were screened. For univariate outliers, standardized z-scores and box-plot were checked. Five cases were detected which exceeded the absolute value of 3.29 (Tabachnick \& Fidell, 2013). Box-plot were also examined. There were a few points that fall away from the box, which was ignored. For multivariate outliers, Mahalanobis distance $\left(D^{2}\right)$ was calculated for each case. Out of 137, nine cases were detected as multivariate outliers with the critical value of $39.252(d f=16$, $\mathrm{p}=.001$ ). After omitting these cases, the analysis was performed again. Secondly, univariate normality was also checked. Kolmogorov-Smirnov and Shapiro-Wilk test results were found significant, which was a sign of non-normal distribution. However, these tests cannot be considered as only indicators for normality because of being very sensitive to sample size. Skewness and kurtosis values were also checked, which were between -3 and +3 . The visual inspection of histogram and Q-Q plots were also observed, in which there was not any evidence for violation of normality. Thus, the univariate normality of the data was assured by skewness and kurtosis values, histogram, and Q-Q plots. Lastly, the adequacy of sample size was checked. According to Bentler and Chou (1987) and Bollen (1989), 5:1 or 10:1, means five or 10 cases for each item was acceptable to perform CFA. The rule was met for 16 items with 128 cases. To sum up, the preliminary analysis was proper for performing confirmatory factor analysis. Upon the recommendation of Tabachnick and Fidell (2013), the maximum likelihood (ML) was chosen as an estimation method for medium to large sample sizes and plausible assumptions. The following fit indices were selected to assess the goodness-of-fit of the model: Chi-square/df, comparative fit index (CFI), non-normed fit index (NNFI) or called as aka Tucker Lewis index (TLI), root mean square error of approximation (RMSEA), and standardized root mean square residual (SRMR) (Jöreskog \& Sörbom, 1993, Kline, 2011). 
The second-order CFA resulted a significant chi-square, $\chi^{2}(100, n=128)=217.83, p=.00$, which indicated an unacceptable model. However, according to Tabachnick and Fidel (2013), chi-square is sensitive to sample size. Thus, other fit indices $(\chi 2 / d f=2.18, \mathrm{CFI}=.89, \mathrm{NNFI}=.87, \mathrm{RMSEA}=0.10$, SRMR $=.09$ ) were examined. In the first run, the only fit index was $\chi 2 / d f$ which showed a good-fitting model because of being under 3.0 (Hu \& Bentler, 1999). CFI and NNFI values showed poor model fitting, which should be greater than .95 for a good model fit, and at least .90 for a moderate model fit (Tabachnick \& Fidell, 2013; Jöreskog \& Sörbom, 1993; Kline, 2011). In addition, RMSEA value greater than .10 indicates a poor-fitting model (Browne \& Cudeck, 1993), which was at the limit in the model. Thus, CFA was performed again to modify the model. Before performing the CFA, modification indices were examined. Four error covariances $(\varepsilon 2-\varepsilon 4, \varepsilon 5-\varepsilon 7, \varepsilon 5-\varepsilon 9$, and $\varepsilon 8-\varepsilon 9)$ were found highly relatively in the program output. Before covarying, the same two experts from Computer Education and Instructional Technology examined the relevant items. As in the previous CFA model, three error covariances were under creation factor. Related items that were creating podcasts, posters, surveys, and presentations; three of them were the same as in the previous model. As mentioned above, these items are Web 2.0 functionalities which allow the users to be a producer on the web. Thus, the experts allow then to covary in the model. Other covariance was under trustworthiness factor. Item 1 "I can distinguish whether information on the web is subjective or scientific." and item 3 "I can distinguish whether information on the web is trustworthy. The experts indicated that the words "scientific" and "trustworthy" might be understood in a similar way, thus allowing them to covary as well.

Table 11.

The model fit indices used for confirmatory factor analysis

\begin{tabular}{lcccll}
\hline \multirow{2}{*}{ Model Fit Index } & \multicolumn{2}{c}{ Acceptable Fit } & \multirow{2}{*}{ Sample Statistics } & Decision & \multirow{2}{*}{ References* } \\
\cline { 2 - 5 } & Moderate Fit & Good Fit & & & \\
\hline$\chi^{2} / \mathrm{df}$ & $<3.0$ or & $<5.0$ & 1.86 & Acceptable & 5 \\
CFI & $.90-.95$ & $.95-1.00$ & .92 & Moderate & $1,2,4$ \\
NNFI & $.90-.95$ & $.95-1.00$ & .90 & Moderate & $1,2,4$ \\
SRMR & $.05-.08$ & $\leq .05$ & .08 & Moderate & 3,5 \\
RMSEA & $.05-.08$ & $\leq .05$ & .08 & Moderate & 3,5 \\
\hline
\end{tabular}

* References: ${ }^{1}$ Tabachnick and Fidell (2013), ${ }^{2}$ Jöreskog and Sörbom (1993), ${ }^{3}$ Browne and Cudeck (1993), ${ }^{4}$ Kline (2011), ${ }^{5} \mathrm{Hu}$ and Bentler (1999),

The results revealed a moderate fit model in the second run of confirmatory factor analysis. The fit indices of the model were as follows: $\mathrm{CFI}=.92, \mathrm{NNFI}=.90, \mathrm{SRMR}=.08$ and RMSEA $=.08$. Chisquare was found significant despite of decreasing the value $\chi^{2}(96, n=128)=179.03, p=.00$. Since this value is sensitive to sample size (Tabachnick \& Fidell 2007), other fit indices should be taken into consideration. $\chi 2 / d f$ was found 1.86 which is an indicator of a moderate fitting model because of being under 3.0 or 5.0 (Hu \& Bentler, 1999). CFI and NNFI values also indicated a moderate model fit, which were found between.90 and .95 (Tabachnick \& Fidell, 2013; Jöreskog \& Sörbom, 1993; Kline, 2011). In addition, RMSEA and SRMR values ranging between .05 and .08 showed moderate fitting model, which was found .08 in the study (Browne \& Cudeck, 1993, Hu \& Bentler, 1999). The model fit indices which selected for the current study were presented in Table 11 . The references for each fit index were also indicated in the table. 


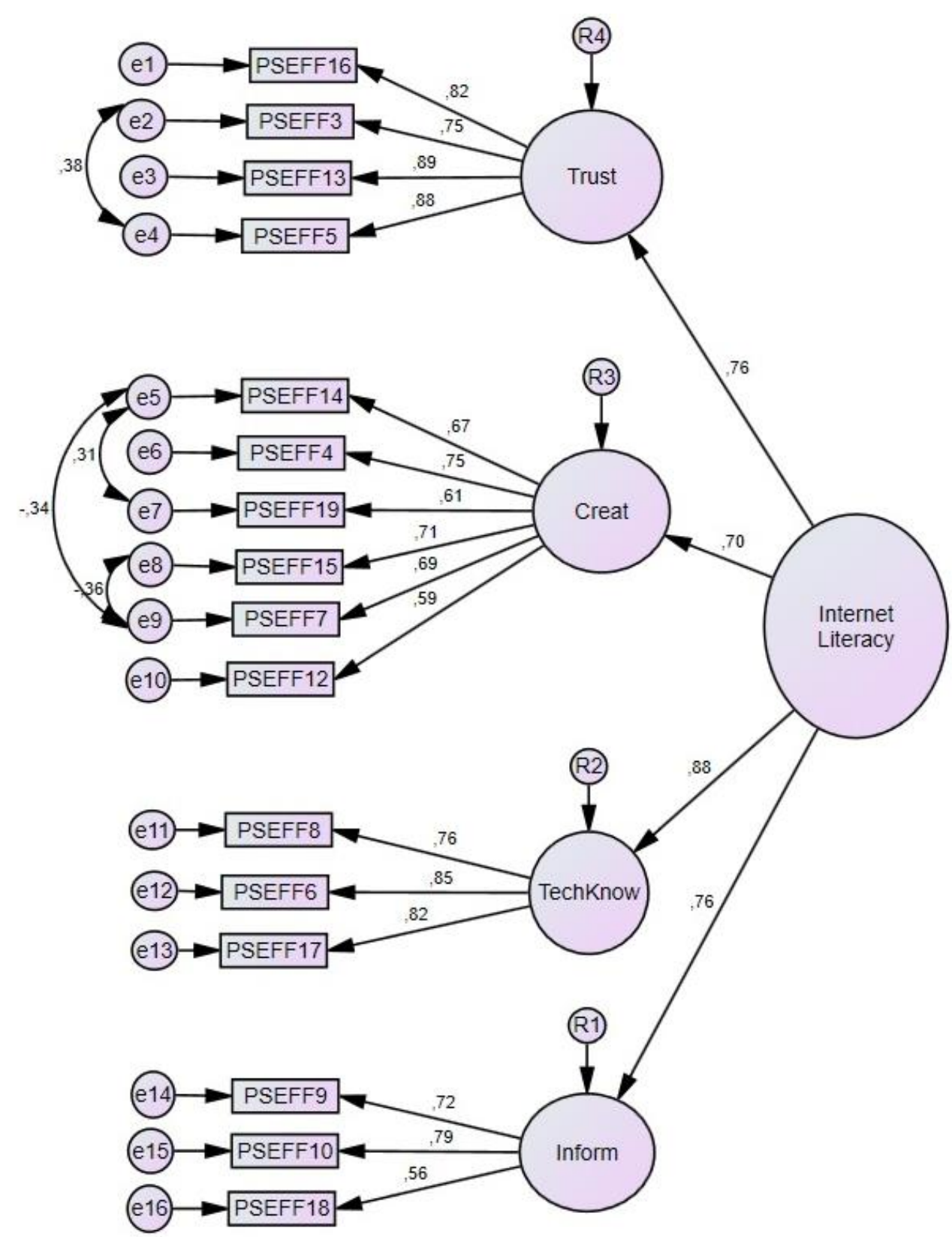

Figure 3. The factor structure of Internet literacy self-efficacy scale with standardized estimates

The proposed second-order factor model of Internet Literacy Self-Efficacy Scale was shown in Figure 3. The standardized factor loadings varied between .75 and .89 for trustworthiness factor, between .59 and .75 for creation factor, between .76 and .85 for technical knowledge factor, and between .56 and .79 for getting information factor. Thus, it can be concluded that all items had a significant contribution to the proposed model since the cut-off point of the standardized estimates of the items was above .40 (Stevens, 2002).

\section{Reliability (b)}

For internal consistency, Cronbach alpha coefficients were examined for each factor, which was found as .90 for trustworthiness factor (4-item), .80 for creation factor (6-item), .83 for technical knowledge factor (3-item), and .71 (3-item) for getting information factor. The rule for acceptable reliability coefficients is determined above .70 (Field, 2009; Kline, 1999). Thus, it can be concluded that subscales had acceptable internal. The coefficients for each item are displayed in Table 12. 
Table 12.

Item-total statistics of factors $(N=128)$

\begin{tabular}{|c|c|c|c|c|c|c|}
\hline & & $\begin{array}{l}\text { Scale Mean if } \\
\text { Item Deleted }\end{array}$ & $\begin{array}{l}\text { Scale Variance if } \\
\text { Item Deleted }\end{array}$ & $\begin{array}{l}\text { Corrected Item- } \\
\text { Total Correlation }\end{array}$ & $\begin{array}{r}\text { Cronbach's Alph } \\
\text { Item Deleted }\end{array}$ & $\begin{array}{l}\text { onbach's Alpha } \\
\text { of Factors }\end{array}$ \\
\hline \multirow{4}{*}{ Trustworthiness } & i3 & 15.36 & 18.44 & .75 & .90 & \multirow{4}{*}{.91} \\
\hline & i5 & 15.35 & 17.24 & .87 & .85 & \\
\hline & i13 & 15.33 & 17.58 & .80 & .88 & \\
\hline & i16 & 15.44 & 18.04 & .75 & .89 & \\
\hline \multirow[t]{6}{*}{ Creation } & i4 & 21.22 & 44.74 & .68 & .77 & \multirow{6}{*}{.82} \\
\hline & i14 & 21.11 & 46.32 & .60 & .79 & \\
\hline & i19 & 21.06 & 47.40 & .63 & .78 & \\
\hline & i12 & 21.05 & 48.80 & .50 & .81 & \\
\hline & i15 & 20.10 & 48.44 & .60 & .79 & \\
\hline & i7 & 21.44 & 49.22 & .51 & .81 & \\
\hline \multirow{3}{*}{$\begin{array}{l}\text { Technical } \\
\text { Knowledge }\end{array}$} & i8 & 8.90 & 10.75 & .69 & .82 & \multirow{3}{*}{.85} \\
\hline & i17 & 8.55 & 10.96 & .74 & .77 & \\
\hline & i6 & 8.61 & 9.96 & .74 & .77 & \\
\hline \multirow{3}{*}{$\begin{array}{l}\text { Getting } \\
\text { Information }\end{array}$} & i10 & 8.80 & 7.42 & .65 & .50 & \multirow{3}{*}{.72} \\
\hline & i18 & 9.45 & 8.36 & .46 & .73 & \\
\hline & i9 & 7.80 & 7.62 & .53 & .65 & \\
\hline
\end{tabular}

\section{Interpretation of Internet Literacy Self-Efficacy Scale (ILSEF) Scores}

The Internet Literacy Self-Efficacy Scale (ILSEF) consists of 16 items. A 7-point Likert-type grading scale [Extremely Confident (7) $\rightarrow$ Not at all confident (1)] was used on the scale. As seen in Table 13, the scale proposed four dimensions: creation (6-item), getting information (3-item), trustworthiness (4item), and technical knowledge (3-item). Therefore, possible scores for each dimension ranging as follows: between 6 and 42 for creation; between 3 and 21 for getting information; between 4 and 28 for trustworthiness; and between 3 and 21 for technical knowledge. For the whole Internet self-efficacy scale, it ranges from 16 to 112 .

Table 13.

The dimensions and items of Internet literacy self-efficacy scale

\begin{tabular}{lcl}
\hline Dimensions & Number of items & \multicolumn{1}{c}{ Items } \\
\hline Creation & 6 & $\mathrm{i} 11, \mathrm{i} 2, \mathrm{i} 16, \mathrm{i} 12, \mathrm{i} 5, \mathrm{i} 9$ \\
Getting Information & 3 & $\mathrm{i} 7, \mathrm{i} 8, \mathrm{i} 15$ \\
Trustworthiness & 4 & $\mathrm{i} 13, \mathrm{i} 1, \mathrm{i} 10, \mathrm{i} 3$ \\
Technical Knowledge & 3 & $\mathrm{i} 4, \mathrm{i} 6, \mathrm{i} 14$ \\
\hline
\end{tabular}

While evaluating the ILSEF scores, the evaluation was made according to both the scores from the subscales and the total score of the scale. This means that besides the dimensions of the scale, the total score related to Internet self-efficacy can be obtained on the scale as well. If the pre-service teachers' scores from the subscales are high, their self-efficacy beliefs in the relevant dimensions are also high. Likewise, a high total score indicates that pre-service teachers' Internet literacy self-efficacy beliefs are high.

\section{DISCUSSION AND CONCLUSION}

The purpose of this study was to develop a valid and reliable scale measuring pre-service teachers' Internet literacy self-efficacy beliefs. The development procedure started with a 19-item draft scale reviewed by experts and students. A pilot study was conducted to determine the structure of the 
measurement tool through exploratory factor analysis (EFA). In addition, structural model validation and construct validity (convergent and discriminant validity) were performed to decide the factor structure of the scale. Then, confirmatory factor analysis was run for validation of the structural model with a second sample. Lastly, internal consistency of the scores was examined for each factor to evaluate the reliability of the scale.

EFA results showed that the Internet Literacy Self-Efficacy Scale (ILSEF) proposed a four-factor structure with 16 items: trustworthiness (4-item), creation (6-item), technical knowledge (3-item), and getting information (3-item). While these four factors explained $65.40 \%$ of the total variance, factor 1 , 2,3 , and 4 accounted for $37.82,13.86,7.24$, and 6.48 of the total variances, respectively. The results of CFA demonstrated a moderate fitting model by checking the following fit indices: $\chi 2 / d f$, CFI, NNFI, SRMR, and RMSEA. Cronbach alpha coefficients were examined for each factor, which was found as .91 for trustworthiness factor, .82 for creation factor, .85 for technical knowledge, and .72 for getting information factor. Being greater than .70, these values were acceptable (Nunally, 1978). To sum up, the results of the study showed that the scores obtained from the developed scale Internet Literacy SelfEfficacy (ILSEF) are valid and reliable for assessing pre-service teachers' Internet literacy self-efficacy.

The ILSEF was developed based on three dimensions of Internet literacy which are access, understanding, and creation (Livingstone et al., 2005). Accordingly, getting information and technical knowledge factors were related to the access dimension. To be Internet literate, the users should improve their skills in searching for information on the web. Using search engines effectively may be considered as a basic level of these skills, while using an online library database and academic reference programs are more advanced levels of them. Another skill in access dimension would be the ability to solve hardware and software Internet access problems for effectively reaching the desired information on the web. Thus, high scores obtained from the factors of getting information and technical knowledge on the scale mean that students have high self-efficacy beliefs in solving Internet access problems and searching for information on the web effectively. Trustworthiness factor is associated with the understanding dimension. There is lots of free information on the web. Although the users have abilities in searching for information, it is also essential that an Internet literate person is able to distinguish trustworthy information. This means that students with high scores from this factor have high selfefficacy beliefs in evaluating whether the information obtained on the web is trustworthy. The last dimension of Internet literacy is creation. It is one of the important functionalities of Web 2.0 technologies that allow the users to create their own content, which is also considered as creation factor on the scale. High scores obtained from this factor mean that students' self-efficacy beliefs in becoming a producer on the web are also high. As a result, the high total score of the students from the scale means that the Internet literacy self-efficacy beliefs are high in terms of all the dimensions mentioned.

In many studies, self-efficacy has been found as one of the potential factors that could affect technology use in the educational environment (Aypay et al., 2012; Oskay, 2011; Moran et. al., 2010; Teo, 2009; Tsai \& Tsai, 2003). In most of these studies, Computer Self-Efficacy Scale (CSEA) (Compeau \& Higgins, 1995) was used to measure self-efficacy beliefs. More specifically, this scale was included in technology acceptance models because of being a one-factor structure. Apart from the CSEA, the other instruments such as Online Technologies Self-Efficacy Scale (OTSES) (Miltiadou \& Yu, 2000), Internet Self-Efficacy (ISE) (Eastin \& LaRose, 2000), Web Users Self-Efficacy Scale (WUSE) (Eachus \& Cassidy, 2006), Use of Internet Self-Efficacy Beliefs Scale for Educational Purposes (Şahin, 2009) and Internet Self-Efficacy Research (ISS) (Kao \& Tsai, 2009) were also examined in the literature. However, none of these have met the needs in terms of measuring Internet literacy self-efficacy beliefs as they include only a few recent web functionalities. Moreover, the most important point is that all of the above-mentioned instruments were for general users or their focus groups were not the students from the faculty of education. Therefore, it was necessary to develop a scale that would provide a comprehensive perspective and up-to-date web functionalities for prospective teachers. In that regard, the present study will help fill this gap in the literature by developing a valid and reliable Internet Literacy Self-Efficacy Scale (ILSEF) for pre-service teachers (see Appendix1). 
The developed scale ILSEF proposed a four-structure model: trustworthiness, creation, technical knowledge, and getting information. Since web technologies change rapidly, different factors should be added to the scale in future studies. Although the scores obtained on the scale were valid and reliable, there were some limitations related to the study. Firstly, the convenience sampling method was used for data collection. This method has some advantages such as being easy or less expensive to carry out, but it is not sufficient to identify target populations (Bornstein, Jager, \& Putnick, 2013). In other words, the generalizability of the results was negatively affected. Moreover, to increase external validity, the instrument should be assessed with different populations. Thus, for further studies, data might be collected from different universities in different regions of Turkey.

\section{Acknowledgements}

A part of this study was presented in EJER' 2018

I would like to thank Dr. Yeşim Çapa Aydın particularly for her valuable feedback in the statistical analyses of my study.

\section{REFERENCES}

Anderson, L., \& Bourke, S. (2000). Assessing affective characteristics in the schools. New York: Routledge. DOI: $10.4324 / 9781410605443$

Angela, T. (2011). A constructivist approach to new media: An opportunity to improve social studies didactics. Procedia-Social and Behavioral Sciences, 11(11), 185-189. DOI: 10.1016/j.sbspro.2011.01.058

Arbuckle, J. L., \& Wothke, W. (1999). Amos 4.0 user's guide. Chicago, IL: Small Waters Corporation.

Aypay, A., Celik, H. C., Aypay, A., \& Sever, M. (2012). Technology acceptance in education: A study of preservice teachers in Turkey. The Turkish Online Journal of Educational Technology, 11(4), 264-272.

Bandura, A. (1977). Self-efficacy: Toward a unifying theory of behavioural change. Psychological Review, 84(2), 191-215. DOI: 10.1037/0033-295X.84.2.191

Bandura, A. (1986). Social foundations of thought and action: A social cognitive theory. Englewood Cliffs, NJ: Prentice-Hall. DOI: 10.1111/1467-839X.00024

Bandura, A. (1998). Self-efficacy. In V. S. Ramachaudran (Ed.), Encyclopedia of human behavior (Vol. 4, pp. 7181). New York: Academic Press. (Reprinted in H. Friedman [Ed.], Encyclopedia of mental health. San Diego: Academic Press.

Bandura, A. (2006). Guide for constructing self-efficacy scales. In Urdan, T., Pajares, F. (Eds.), Self-efficacy beliefs of adolescents, 5, 307-337. Greenwich, CT: Information Age.

Bentler, P. M., \& Chou, C. P. (1987). Practical Issues in Structural Modeling. Sociological Methods \& Research, 16(1), 78-117. DOI: $10.1177 / 0049124187016001004$

Bollen. A. (1989). Structural Equations with Latent Variables. New York: Jon Wiley \& Sons. DOI: $10.1002 / 9781118619179$

Bong, M., \& Skaalvik, E. M. (2003). Academic self-concept and self-efficacy: How different are they really? Educational psychology review, 15(1), 1-40. DOI: 10.1023/A:1021302408382

Bong, M., \& Clark, R. E. (1999). Comparison between self-concept and self-efficacy in academic motivation research. Educational psychologist, 34(3), 139-153. DOI: 10.1207/s15326985ep3403_1

Bornstein, M. H., Jager, J., \& Putnick, D. L. (2013). Sampling in developmental science: Situations, shortcomings, solutions, and standards. Developmental Review, 33(4), 357-370. DOI: 10.1016/j.dr.2013.08.003

Browne, M. W., \& Cudeck, R. (1993). Alternative ways of assessing model fit. In K. A. Bollen \& J. S. Long (Eds.), Testing structural equation models (pp. 136-162). Newbury Park, CA: Sage.

Büyüköztürk, Ş. (2007). Sosyal bilimler için veri analizi el kitabı (7. Baskı). Ankara: Pegem Akademi Yayınları.

Compeau, D. R., \& Higgins, C. A. (1995). Computer self-efficacy: Development of a measure and initial test. MIS Quarterly, 19(2), 189-211. DOI: $10.2307 / 249688$

Cortina J. M. (1993). What is coefficient alpha? An examination of theory and applications. Journal of Applied Psychology, 78(1), 98-104. DOI: 10.1037/0021-9010.78.1.98 
Eachus, P., \& Cassidy, S. (2006). Development of the web users self-efficacy scale (WUSE). Issues in Informing Science and Information Technology Journal, 3, 199-209. Retrieved from http://usir.salford.ac.uk/id/eprint/1172

Eastin, M. S., \& LaRose, R. (2000). Internet self-efficacy and the psychology of the digital divide. Journal of computer-mediated communication, 6(1), JCMC611. DOI: 10.1111/j.1083-6101.2000.tb00110.x

Fabrigar, L. R., Wegener, D. T., MacCallum, R. C., \& Strahan, E. J. (1999). Evaluating the use of exploratory factor analysis in psychological research. Psychological methods, 4(3), 272-299. DOI: 10.1037/1082989X.4.3.272

Ferrari, A. (2012). Digital competence in practice: An analysis of frameworks (Report EUR 25351 EN). Luxembourg: Publications Office of the European Union. Retrieved from http://ftp.jrc.es/EURdoc/JRC68116.pdf

Field. A. (2009). Discovering statistics using by SPSS ( $3^{\text {rd }}$ ed.). London: Sage Publication.

Fornell, C., \& Larcker, D. F. (1981). Evaluating structural equation models with unobservable variables and measurement error. Journal of Marketing Research, 18(1), 39-50. DOI: 10.1177/2F002224378101800104

Greenhow, C., Robelia, B., \& Hughes, J. E. (2009). Learning, teaching, and scholarship in a digital age: Web 2.0 and classroom research: What path should we take now? Educational Researcher,38(4), 246-259.

Gouveia, V. V., \& Soares, A. K. S. (2015). Calculadoras de validade de construto (CVC). João Pessoa, PB: BNCS/ Universidade Federal da Paraíba, [Construct Validity Calculators (CVC)] Retrieved from http://akssoares.com/psicometria/calculadora-vme-e-cc

Joo, Y. J., Bong, M., \& Choi, H. J. (2000). Self-efficacy for self-regulated learning, academic self-efficacy, and Internet self-efficacy in web-based instruction. Educational Technology and Development, 48(2), 5-17 DOI: $10.1007 / \mathrm{BF} 02313398$

Jöreskog, K. G., \& Sörbom, D. (1993). LISREL 8: Structural equation modeling with the SIMPLIS command language. Chicago: Scientific Software International.

Hair, J. F., Anderson, R. E., Tatham, R. L., \& Black, W. C. (2010). Multivariate Data Analysis (7 ${ }^{\text {th }}$ ed.). Upper

Saddle River, NJ: Prentice Hall, Inc.

Hill, P., Jensen, N., Read, N., \& MacArthur, S. (2013). Google Search: Techniques. All Current Publications. Paper 356.

Hooper, D., Coughlan, J., \& Mullen, M. R. (2008). Structural equation modelling: Guidelines for determining model fit. Electronic Journal of Business Research Methods, 6(1), 53-60. Retrieved from http://mural.maynoothuniversity.ie/6596/

Hu, L. H., \& Bentler, P. M. (1999). Cutoff criteria for fit indexes in covariance structure analysis: Conventional criteria versus new alternatives. Structural Equation Modeling: A Multidisciplinary Journal, 6 (1), 1-15. DOI: 10.1080/10705519909540118

Humphreys, L. G., \& Montanelli, R. G. (1975). An investigation of the parallel analysis criterion for determining the number of common factors. Multivariate Behavioral Research, 10, 193-206.

Kalayc1, Ş. (2008). SPSS uygulamalı çok değişkenli istatistik teknikleri (3 ${ }^{\text {th }}$ ed.). [SPSS applied multivariate statistics techniques]. Ankara: Asil Yayın Dağıtım.

Kaya, S., \& Durmuş, A. (2010). Pre-service teachers' perceived Internet self-efficacy and levels of Internet use for research. Procedia-Social and Behavioral Sciences, 2(2), 4370-4376. DOI: 10.1016/j.sbspro.2010.03.695

Kao, C. P., \& Tsai, C. C. (2009). Teachers' attitudes toward web-based professional development, with relation to Internet self-efficacy and beliefs about web-based learning. Computers \& Education, 53(1), 66-73. DOI: 10.1016/j.compedu.2008.12.019

Kao, C. P., Wu, Y. T., \& Tsai, C. C. (2011). Elementary school teachers' motivation toward web-based professional development, and the relationship with Internet self-efficacy and belief about web-based learning. Teaching and Teacher Education, 27(2), 406-415. DOI: 10.1016/j.tate.2010.09.010

Kiyıc1, F. B. (2010). The definitions and preferences of science teacher candidates concerning web 2.0 tools: A phenomenological research study. The Turkish Online Journal of Educational Technology, 9(2), 185-195. Retrieved from http://www.tojet.net/articles/v9i2/9219.pdf

Kim, Y., Glassman, M., Bartholomew, M., \& Hur, E. H. (2013). Creating an educational context for Open Source Intelligence: The development of Internet self-efficacy through a blog-centric course. Computers \& Education, 69, 332-342. DOI: 10.1016/j.compedu.2013.07.034

Kline, P. (1999). A Handbook of Psychological Testing, ( $2^{\text {nd }}$ ed.). London: Routledge. DOI: $10.4324 / 9781315812274$

Kline, R. B. (2011). Principles and practice of structural equation modeling ( $2^{\text {nd }}$ ed.). New York: The Guilford Press.

Kurbanoglu, S. S. (2003). Self-efficacy: A concept closely linked to information literacy and lifelong learning. Journal of Documentation, 59(6), 635-646. DOI: 10.1108/00220410310506295 
Ledesma, Rubén Daniel and Valero-Mora, Pedro (2007) "Determining the Number of Factors to Retain in EFA: An easy-to-use computer program for carrying out Parallel Analysis," Practical Assessment, Research, and Evaluation, 12(2).

Laver, K., George, S., Ratcliffe, J., \& Crotty, M. (2012). Measuring technology self-efficacy: Reliability and construct validity of a modified computer self-efficacy scale in a clinical rehabilitation setting. Disability and rehabilitation, 34(3), 220-227. DOI: 10.3109/09638288.2011.593682

Lee, L., Chen, D. T., Li, J. Y., \& Lin, T. B. (2015). Understanding new media literacy: The development of a measuring instrument. Computers \& Education, 85, 84-93. DOI: 10.1016/j.compedu.2015.02.006

Liaw, S. S., Huang, H. M., \& Chen, G. D. (2007). Surveying instructor and learner attitudes toward e-learning. Computers \& Education, 49(4), 1066-1080. DOI: 10.1016/j.compedu.2006.01.001

Livingstone, S., M. Bober and E.J. Helsper (2005) Internet Literacy Among Children and Young People: Findings from the UK Children Go Online Project. London: London School of Economics and Political Science. Retrieved from www.children-go-online.net

McCoach, D. B., Gable, R. K., \& Madura, J. P. (2013). Affective characteristics in school and corporate environments: Their conceptual definitions. In D. B. McCoach, R. K. Gable \& J. P. Madura (Eds.), Instrument Development in the Affective Domain. New York: Springer. DOI: 10.1007/978-1-4614-71356_1

Miltiadou, M., \& Yu, C. H. (2000). Validation of the online technologies self-efficacy scale (OTSES). Educational Technology Review, 11(1), 1-11.

Moran, M., Hawkes, M., \& Gayar, O. E. (2010). Tablet personal computer integration in higher education: Applying the unified theory of acceptance and use technology model to understand supporting factors. Journal of Educational Computing Research, 42(1), 79-101. DOI: 10.2190\%2FEC.42.1.d

Nunnally, J. C. (1967). McGraw-Hill series in psychology. Psychometric theory. New York, NY, US: McGrawHill.

Nunnally, J. C. (1978). Psychometric Theory, 2nd ed. New York: McGraw-Hill.

Oskay, Ö.Ö. (2011). Internet self-efficacy preferences of Internet-based environments and achievement of prospective teachers. Hacettepe University Journal of Education, 40, 291-299. https://www.learntechlib.org/p/51226/

Özdamar, K. (1997). Paket programlar ve istatistiksel veri analizi. [Statistical data analysis with package programs]. Eskişehir: Anadolu Üniversitesi Yayınları.

Peterson, R. A. (1994). A meta-analysis of Cronbach's coefficient alpha. Journal of Consumer Research, 21(2), 381-391. DOI: $10.1086 / 209405$

Preacher, K. J., \& MacCallum, R. C. (2003). Repairing Tom Swift's electric factor analysis machine. Understanding statistics: Statistical issues in psychology, education, and the social sciences, 2(1), 13-43. DOI: $10.1207 /$ S15328031US0201_02

Rosenberg, M. (1965). The Rosenberg self-esteem scale: From society and the adolescent self-image. Princeton, NJ: Princeton University Press.

Sang, G., Valcke, M., van Braak, J., \& Tondeur, J. (2010). Student teachers' thinking processes and ICT integration: Predictors of prospective teaching behaviors with educational technology. Computers \& Education, 54(1), 103-112. DOI: 10.1016/j.compedu.2009.07.010

Stevens, J. P. (2002). Applied multivariate statistics for the social sciences (4. ed.). Hillsdale, NJ: Erlbaum.

Sun, J. C. Y., \& Rueda, R. (2012). Situational interest, computer self-efficacy and self-regulation: Their impact on student engagement in distance education. British Journal of Educational Technology, 43(2), 191-204. DOI: $10.1111 /$ j.1467-8535.2010.01157.x

Şad, S. N., \& Demir, O. (2015). Computer and Internet Use Self-Efficacy Scale for Elementary School Teachers: Validity and Reliability Studies. Elementary Education Online, 14(2), 489-510. DOI: 10.17051/io.2015.00172

Şahin, İ. (2009). Validity and reliability of educational Internet use self-efficacy beliefs scale. Selçuk Üniversitesi Sosyal Bilimler Enstitüsü Dergisi, 21, 459-471. Retrieved from http://dergisosyalbil.selcuk.edu.tr/susbed/article/view/338

Tabachnick, B. G., \& Fidell, L. S. (2013). Using multivariate statistics. Needham Heights, MA: Allyn and Bacon.

Tella, A. (2011). An assessment of mathematics teachers' Internet self-efficacy: implications on teachers' delivery of mathematics instruction. International Journal of Mathematical Education in Science and Technology, 42(2), 155-174. DOI: 10.1080/0020739X.2010.519798

Teo, T. (2009). Modelling technology acceptance in education: A study of pre-service teachers. Computers \& Education, 52(2), 302-312. DOI: 10.1016/j.compedu.2008.08.006

Teo, T., \& Koh, J. H. L. (2010). Assessing the dimensionality of computer self-efficacy among pre-service teachers in Singapore: A structural equation modeling approach. International Journal of Education and Development using Information and Communication Technology, 6(3), 7. https://www.learntechlib.org/p/42385/ 
Terzis, V., \& Economides, A. A. (2011). The acceptance and use of computer-based assessment. Computers \& Education, 56(4), 1032-1044. DOI: 10.1016/j.compedu.2010.11.017

Timothy, T. E. O. (2009). Examining the relationship between student teachers' self-efficacy beliefs and their intended uses of technology for teaching: A structural equation modelling approach. The Turkish Online Journal of Educational Technology, 8(4), 7-15.

Thompson, B. 2008. Exploratory and Confirmatory Factor Analysis: Understanding Concepts and Applications. 3rd ed. Washington, DC: American Psychological Association.

Tsai, M.-J., \&Tsai, C.-C. (2003) Information searching strategies in web-based science learning: the role of Internet self-efficacy. Innovations in Education and Teaching International, 40(1), 43-50. DOI: $10.1080 / 1355800032000038822$

Wang, L., Ertmer, P. A., \& Newby, T. J. (2004). Increasing preservice teachers' self-efficacy beliefs for technology integration. Journal of Research on Technology in Education, 36(3), 231-250. DOI: 10.1080/15391523.2004.10782414

Willis, G.B. (2005). Cognitive interviewing: A tool for improving questionnaire design. Thousand Oaks, CA: SAGE.

Wong, K. T., Teo, T., \& Russo, S. (2012). Influence of gender and computer teaching efficacy on computer acceptance among Malaysian student teachers: An extended technology acceptance model. Australasian Journal of Educational Technology, 28(7), 1190-1207. DOI: 10.14742/ajet.796

Venkatesh, V., \& Davis, F. D. (1996). A model of the antecedents of perceived ease of use: Development and test. Decision sciences, 27(3), 451-481. DOI: 10.1111/j.1540-5915.1996.tb00860.x

Venkatesh, V., Morris, M. G., Davis, G. B., \& Davis, F. D. (2003). User acceptance of information technology: Toward a unified view. MIS Quarterly, 27(3), 425-478. DOI: $10.2307 / 30036540$

Yasan-Ak, N. (2018). The investigation of undergraduate students' mobile phone use in the academic environment: The case of middle east technical university (Unpublished doctoral dissertation). Middle East Technical University, Turkey.

Young, J. A. (2015). Assessing new media literacies in social work education: The development and validation of a comprehensive assessment instrument. Journal of Technology in Human Services, 33(1), 72-86. DOI: $10.1080 / 15228835.2014 .998577$

Yurdugül, H., \& Aşkar, P. (2008). An investigation of the factorial structures of pupils' attitude towards technology (PATT): A Turkish sample. Elementary Education Online, 7(2), 288-309.

Yurdugül, H., \& Sirakaya, D. A. (2013). The scale of online learning readiness: A study of validity and reliability. Eğitim ve Bilim [Education and Science], 38(169), 391-406.

Zimmerman, B. J. (2000). Self-efficacy: An essential motive to learn. Contemporary Educational Psychology, 25(1), 82-91. DOI: 10.1080/15228835.2014.998577

Zwick, W.R. \& Velicer, W.F. (1986). Comparison of five rules for determining the number of components to retain. Psychological Bulletin, 99, 432-442. 


\section{APPENDIX 1}

\section{Internet Literacy Self-Efficacy Scale for Pre-service Teachers (in English)}

\begin{tabular}{|c|c|c|c|c|c|c|c|c|}
\hline & $\begin{array}{c}\text { Please use the } 1-7 \text { scale provided ("Not at all confident" to "Extremely } \\
\text { onfident") to rate how much you feel confident about being able to the given } \\
\text { statements. }\end{array}$ & 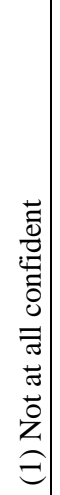 & $\widehat{d}$ & $\widehat{(2)}$ & 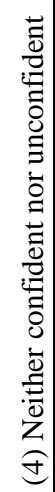 & $\widehat{c}$ & e & 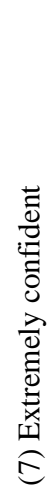 \\
\hline 1 & I can distinguish whether information on the web is subjective or scientific. & & & & & & & \\
\hline 2 & I can create videos on the web (e.g. GoAnimate, Powtoon, etc.). & & & & & & & \\
\hline 3 & I can distinguish whether information on the web is trustworthy. & & & & & & & \\
\hline 4 & I can solve software-related Internet access problems. & & & & & & & \\
\hline 5 & I can create podcasts. & & & & & & & \\
\hline 6 & I can solve other Internet access problems. & & & & & & & \\
\hline 7 & I can use Google search techniques. & & & & & & & \\
\hline 8 & I can use online library databases. & & & & & & & \\
\hline 9 & I can create blogs. & & & & & & & \\
\hline 10 & I can distinguish trustworthy web sites. & & & & & & & \\
\hline 11 & I can create posters or concept maps (e.g. Bubbl.us, Easel.ly, etc.). & & & & & & & \\
\hline 12 & I can create presentations on the web (e.g. Prezzi, Slides, etc.). & & & & & & & \\
\hline 13 & $\begin{array}{l}\text { I can distinguish whether the source of information on the web is scientific } \\
\text { or not. }\end{array}$ & & & & & & & \\
\hline 14 & I can solve hardware-related Internet access problems. & & & & & & & \\
\hline 15 & I can use academic reference programs (e.g. Mendeley, Evernote, etc.). & & & & & & & \\
\hline 16 & I can create surveys (e.g. SurveyMonkey, Obsurvey, GoogleForms, etc.). & & & & & & & \\
\hline
\end{tabular}




\section{TÜRKÇE GENIŞLETILMIŞ ÖZET}

Web teknolojileri yeni işlevler kazandıkça, bu teknolojileri kullanma becerilerini geliştirme gerekliliği de artmıştır. Bu nedenle, İnternet okuryazarlığı, daha geniş anlamda medya okuryazarlığının önemi günden güne önem kazanmaktadır. Kuşkusuz teknolojideki bu hızlı değişim eğitim sistemini de etkilemektedir. Angele'nın (2010) belirttiği gibi yeni medya teknolojilerin bilgi kaynağına olan erişimi arttırmasıyla öğretmen ve öğrenciler için yeni ögrenme ortamları oluşturmuş, böylece eğitimde teknoloji entegrasyonu bir ihtiyaç haline gelmiştir (Young, 2015).

Son zamanlarda teknoloji kullanımının öğrenmeye ve öğretmeye olan etkisi ve hangi değişkenlerin bu etkiyi yordadığ 1 önemli bir araştırma konusudur (Teo \& Koh, 2010). Bu anlamda, Sosyal Bilişsel Kuramın anahtar değişkenlerinden olan özyeterliğin birçok teknoloji kabul çalışmasında önemli bir değişken olarak ele alındığı görülmüştür (Aypay, Çelik, Aypay, \& Sever, 2012; Moran, Hawkes, \& Gayar, 2010; Teo, 2009; Wong, Teo, \& Russo, 2012; Venkatesh \& Davis, 1996; Vankatesh, Morris, Davis, \& Davis, 2003). Böylece, birçok farklı teknoloji kullanımı için özyeterlik inançlarını ölçme ihtiyacı duyulmuştur. Bilgisayar kullanım özyeterliği, web kullanım özyeterliği, İnternet kullanım özyeterliği bunlardan birkaçı olarak sayılabilir.

$\mathrm{Bu}$ çalışmada amaçlanan öğretmen adaylarının İnternet okuryazarlık özyeterlik inançlarının değerlendirilmesi için geliştirilen Likert tipi bir ölçeğin geçerlik ve güvenirlik çalışmasını yapmaktır. Veriler, Türkiye'deki bir devlet üniversitesindeki eğitim fakültesinin 8 farklı bölümünden ve tüm sinıf düzeylerinden toplanmıştır. 174 ve 150 öğretmen adayından oluşan iki farklı çalışma grubu kullanılmıştır.

Ölçeğin geliştirilme süreci ilk olarak İnternet okuryazarlığı üzerine kapsamlı bir literatür taramasıyla başlanmıştır. Buna göre, araştırmacı tarafından 27 maddelik bir başlangıç madde havuzu oluşturulmuştur. İçerik uzmanlar tarafından incelenmiş ve ayrıca olası yanıt hatalarını kontrol etmek için öğrencilerle bilişsel görüşmeler yapılmıştır. Uzmanlardan ve öğrencilerden alınan geribildirimler ile gerekli değişiklikler yapılmış, 19 maddeden oluşan bir ölçekle veri toplamaya çıkılmıştır.

Veri toplamadan önce ilgili üniversite için Uygulamalı Etik Araştırma Merkezi'nden etik onay alınmıştır. Veriler 2017-2018 güz döneminde ve 2018-2019 bahar döneminde toplanmıştır. Araştırmacı, ölçek teknolojik kabiliyeti ölçtüğü için anket formlarını elden dağıtmıştır. Ölçeğin iç geçerliğini negatif yönde etkilemesinin önüne geçmek için çevrimiçi anketler tercih edilmemiştir. Anketin tamamlanması yaklaşık 10 dakika sürmüştür. Öğrenciler çalışmaya gönüllü olarak katılmış ve yanıtlarının gizliliği hakkında bilgilendirilmişlerdir.

Öğrencilere dağıtılan anket iki ana bölümden oluşmaktadır. İlk bölüm geliştirilen ölçek iken, demografik bilgiler (cinsiyet, yaş, eğitim yıll, bölüm ve genel not ortalaması) anketin ikinci bölümünden toplanmıştır. Bu bölüm aynı zamanda teknoloji kullanımıyla ilgili bazı soruları da içermektedir. $\mathrm{Bu}$ sorular şöyledir: Lisans programlarında alınan ders sayısı, günlük İnternet kullanımı, derslerde BİT kullanım düzeyi ve ödevdeki öğrencilerin BİT kullanım düzeyi. Betimsel analiz sıklıklar, yüzdeler, ortalamalar ve standart sapmalar ile sunulmuştur.

İnternet Okuryazarlığı Özyeterlik Ölçeğinin güvenirlik ve geçerlik çalışmaları için çeşitli istatistiksel analizler yapılmıştır. İlk olarak ölçeğin faktör yapısını keşfetmek için Açımlayıcı Faktör Analizi (AFA) çalıştırılmıştır. Bu analizde Oblimin rotasyonlu Principal Axis Factoring (PAF) ekstraksiyon yöntemi kullanıldı. İkinci olarak ölçeğin faktör yapısını doğrulamak için Doğrulayıcı Faktör Analizi (DFA) yapılmıştır. Daha sonra, ölçeğin yapı geçerliliği yakınsak geçerlik ve ayırıcı geçerlik olmak üzere iki yöntemle de kontrol edilmiştir. Son olarak, ölçeğin güvenirlik analizleri farklı iki örneklem kullanılarak 
test edilmiştir. SPSS 20.0 açımlayıcı faktör analizi ve betimsel analiz için kullanılırken, doğrulayıcı faktör analizi AMOS 20.0 yazılımı kullanılarak yapılmıştır.

İstatistiksel analizlere başlamadan önce, verilerde herhangi bir kayıp veri ya da yanlış veri girişimi olup olmadığı incelenmek üzere taranmıştır. Ayrıca çalışmada kullanılan örneklem sayısının AFA ve DFA gerçekleştirebilmek için yeterli olup olmadığ da çeşitli analizlerle test edilmiştir. Sonuç olarak örneklemin AFA ve DFA çalıştırmak için uygun olduğu tespit edilmiştir.

Açımlayıcı faktör analizi ilk çalıştırıldığı zaman beş faktörlü bir yapı oluşmuştur. Ancak bu yapıda bazı maddelerin yük değerlerinin .30'un altında kaldığı, bazılarının birden fazla faktöre yük verdiği görülmüştür. Uygun olmayan üç maddenin ölçekten çıkarılmasıyla analiz 16 maddeyle tekrarlanmış ve 4 faktörlü bir yapı elde edilmiştir. Bu 16 maddeli dört faktörlü yapı ölçeğin toplam varyansın \%65,40'ını açıklamaktadır. Her bir faktörün modele olan katkısı ayrı ayrı incelendiğinde ise Güvenilirlik olarak isimlendirilen birinci faktör toplam varyansın \%37,82'sini; ikinci faktör olan Oluşturma \%13,86'sını, Teknik Bilgi olan üçüncü faktör \% 7.24'ünü ve dördüncü faktör olan Bilgi Edinme ise toplam varyansın \%6.48'ini açıkladığı görülmüştür. Ölçeğin faktör sayısı scree plot ve Kaiser'in özdeğerleri dışında, paralel analiz yapılarak da tespit edilmeye çalışılmışıı. Paralel analiz sonuçları scree plot ve eigen değerleri sonuçlarından farklı olarak iki faktörlü bir yapı modeli sunmuştur. Faktör yapısını netleştirmek için alternatif modeller sunularak yapısal model geçerlilik test edilmiştir. Tek faktörlü, iki faktörlü, dört faktörlü (ilişskili), dört faktörlü (ilişkisiz) ve en son olarak dört faktörlü (ilişkili ve modifikasyonlu) model olmak üzere beş farklı model sunulmuştur. Bunların arasında beşinci modelin AFA sonucunun önerdiği dört-faktörlü (ilişkili ve modifikasyonlu) modelin en iyi uyum indeksi gösterdiği görülmüsstür. Ayrıca ölçekteki maddelerin önerilen modeldeki dört faktörü ne ölçüde yansıttığını tespit etmek için yapı geçerliği test edilmiştir (Yurdugül \& Sırakaya, 2013). Bunun için yakınsak geçerlik ve ayırt edici geçerlik yöntemleri kullanılmıştır. Analiz sonuçlarına göre geliştirilen ölçeğin yapı geçerliğinde herhangi bir problem olmadığg görülmüsstür. Bütün bu analizler ölçeğin 16 maddeli dört faktörlü bir yapıyı desteklediğini ortaya koymuştur.

İnternet Okuryazarlığı Öz-Yeterlik Ölçeğinin dört faktörlü çözüm modelini doğrulamak için ikinci örneklem kullanılarak ikinci mertebe doğrulayıcı faktör analizi (DFA) yapılmıştır (Arbuckle \& Wothke, 1999). DFA analize uygunluğu ön analizlerle tespit edilmiştir. Modelin uyumunu değerlendirmek için, $\chi^{2 / d f}$, karşılaş̧ırmalı uyum indeksi (CFI), normlaştırılmamış uyum indeksi (NNFI) veya Tucker Lewis indeksi (TLI), kök ortalama kare yaklaşık hatası (RMSEA) ve standardize edilmiş kök ortalama kare hatası (SRMR) (Jöreskog \& Sörbom, 1993, Kline, 2011) rapor edilmiştir. Buna göre, model veri uyumunun orta düzeyde olduğunu görülmüştür. Bunun dışında, ölçeğin standartlaştırılmış faktör yükleri .56 ile .85 arasında bulunmuştur. Maddelerin standartlaştırılmış tahminlerinin kesme noktası 0.40 'ı üzerinde olduğu düşünülürse tüm maddelerin önerilen modele önemli bir katkı sağladığı sonucuna varılabilir (Stevens, 2002). Ayrıca her bir faktör için iç tutarlılık güvenirlik katsayıları hesaplanmıştır. Güvenilirlik, Oluşturma, Teknik Bilgi ve Bilgi Alma faktörlerinin Cronbach alfa katsayıları sırasıyla $.91, .82, .85$ ve .72 'dir. Kabul edilebilir güvenilirlik katsayıları için kural .70 olduğuna göre ölçeğin güvenilir olduğu anlaşılmıştır (Field, 2009; Kline, 1999).

Özetle, yapılan bu çalışmada İnternet Okuryazarlığı Özyeterlik Ölçeğinden elde edilen puanların öğretmen adaylarının İnternet okuryazarlığ 1 özyeterliklerinin değerlendirilmesinde geçerli ve güvenilir bir yapıda olduğu ortaya konmuştur. ILSEF puanları değerlendirilirken değerlendirme hem alt ölçeklerden alınan puanlarla hem de ölçeğin toplam puanına göre yapılmıştır. Yani, öğretmen adaylarının alt ölçeklerden aldıkları puanlar yüksekse, ilgili boyutlardaki öz-yeterlik inançları da yüksektir. Benzer şekilde, ölçekten alınan toplam puanın yüksek olması öğretmen adaylarının İnternet okuryazarlığı öz-yeterlik inançlarının yüksek olduğunu göstermektedir. 


\section{EK 1}

\section{Öğretmen Adayları İçin İnternet Okuryazarlığı Özyeterlik Ölçeği (Türkçe)}

\begin{tabular}{|c|c|c|c|c|c|c|c|c|}
\hline & $\begin{array}{l}\text { Öğretmen Adayları İçin İnternet Okuryazarlığı Özyeterlik Ölçeği } \\
\text { Verilen ifadeleri yapabilme konusunda kendinize ne kadar güvendiğinizi } \\
\text { l (Kendime Hiç Güvenmiyorum) - } 7 \text { (Kendime Çok Güveniyorum) arasinda } \\
\text { derecelendiriniz. }\end{array}$ & 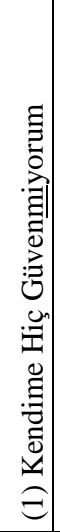 & $\widehat{d}$ & $\overparen{(0)}$ & 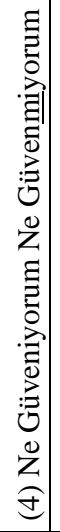 & 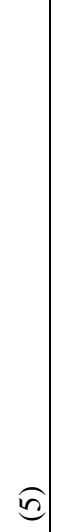 & e & 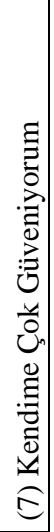 \\
\hline 1 & Web sitelerinde bilimsel bilgiyle yanlı bilgiyi ayırt edebilirim. & & & & & & & \\
\hline 2 & Web üzerinden video oluşturabilirim (Örnek: GoAnimate, Powtoon...vb.). & & & & & & & \\
\hline 3 & Web sitelerindeki bilginin güvenilir olup olmadığının ayrımını yapabilirim. & & & & & & & \\
\hline 4 & $\begin{array}{l}\text { Yazılımsal İnternet erişim problemlerini çözebilirim (Örnek: Ağ ayarları, } \\
\text { bağlantı hızının yavaşlaması...vb.). }\end{array}$ & & & & & & & \\
\hline 5 & $\begin{array}{l}\text { Podcast oluşturabilirim (İnternette yayınlamak amacıyla ses ve video } \\
\text { dosyaları oluşturma). }\end{array}$ & & & & & & & \\
\hline 6 & $\begin{array}{l}\text { İnternet'i kullanırken oluşan diğer problemleri çözebilirim (Örnek: Flash } \\
\text { Player yükleme, virüslü sayfalara yönlendirme...vb. ile ilgili problemler). }\end{array}$ & & & & & & & \\
\hline 7 & $\begin{array}{l}\text { Google arama tekniklerini etkili kullanabilirim (ve-veya bağlaçlarını } \\
\text { kullanma, sözcüğü tırnak içine alma...vb.). }\end{array}$ & & & & & & & \\
\hline 8 & Web üzerinden kütüphane veri tabanlarını etkili kullanabilirim. & & & & & & & \\
\hline 9 & Blog oluşturabilirim (Kendi oluşturduğum Web günlüğü sayfasına yazma). & & & & & & & \\
\hline 10 & Güvenilir web sitelerini ayırt edebilirim. & & & & & & & \\
\hline 11 & Poster, kavram haritası oluşturabilirim (Örnek: Bubbl.us, Easel.ly...vb.). & & & & & & & \\
\hline 12 & Web üzerinden sunum hazırlayabilirim (Örnek: Prezzi, Slides...vb.). & & & & & & & \\
\hline 13 & $\begin{array}{l}\text { Web sitelerindeki bilginin bilimsel kaynaktan olup olmadığını ayırt } \\
\text { edebilirim. }\end{array}$ & & & & & & & \\
\hline 14 & $\begin{array}{l}\text { Donanımsal İnternet erişim problemlerini çözebilirim (Örnek: Modem, } \\
\text { kablo...vb. ile ilgili problemler.). }\end{array}$ & & & & & & & \\
\hline 15 & $\begin{array}{l}\text { Akademik referans ve not alma bilişim araçlarını kullanabilirim (Örnek: } \\
\text { Mendeley, EverNote...vb.). }\end{array}$ & & & & & & & \\
\hline 16 & $\begin{array}{l}\text { Anket hazırlayabilirim (Örnek: SurveyMonkey, Obsurvey, } \\
\text { GoogleForms...vb.). }\end{array}$ & & & & & & & \\
\hline
\end{tabular}

